PALAIOS

Emphasizing the impact of life on Earth's history

\title{
EVIDENCE OF BACTERIAL DECAY AND EARLY DIAGENESIS IN A PARTIALLY ARTICULATED TETRAPOD FROM THE TRIASSIC CHAÑARES FORMATION
}

\author{
ADRIANA CECILIA MANCUSO, ELENA PREVITERA, CECILIA ANDREA BENAVENTE, AND SANTIAGO HERNANDEZ DEL PINO \\ IANIGLA, CCT-CONICET-Mendoza, Avda. Ruiz Leal s/n Parque Gral. San Martín (5500) Mendoza, Argentina \\ email: amancu@mendoza-conicet.gov.ar
}

\begin{abstract}
The vertebrate fauna from the lower Carnian Chañares Formation of Argentina is dominated by wellpreserved small- and medium-bodied archosauriforms and therapsids. Here we report the discovery of a nonmammalian therapsid dicynodont (of greater than $20 \mathrm{~cm}$ skull length) that was found partially articulated within the floodplain deposit. Taphonomic analysis of this specimen reveals details of its paleobiology and taphonomic history, including the cause of death, exposure to predation and/or scavenging, subsequent subaerial decay, and final entombment. The specimen studied also allowed for the documentation of the activity of micro-organisms involved in decay processes during the biostratinomic stage (soft tissue decomposition on surface) and diagenetic stages (anaerobic decay). Our results indicate that despite bones being found in concretions the formation of calcareous concretions is not required for bone preservation. Consequently, this study highlights the role of volcanic ash in promoting bone preservation.
\end{abstract}

\section{INTRODUCTION}

The Triassic Chañares Formation $(\mathrm{CF})$ is characterized by its extraordinary preservation of small- and medium-bodied archosauriforms and cynodont therapsids (Rogers et al. 2001; Mancuso et al. 2014). This formation preserves representatives of the early Carnian tetrapod fauna, including proterochampsids, early offshoots of the crocodilian line, precursors of the dinosaurian lineage, dicynodonts, and cynodonts (Romer and Jensen 1966; Rogers et al. 2001; Mancuso et al. 2014; Marsicano et al. 2015).

The Chañares tetrapod record shows two different accumulation modes: an attritional mortality assemblage ( $\sim 35 \%$ of specimens recovered) and a mass-mortality assemblage ( $\sim 65 \%$ of specimens recovered) (Mancuso et al. 2014). The former mode occurs in the lowest levels of the formation. It includes the largest animals ( 30 to $60 \mathrm{~cm}$ skull length), and represents all taxonomic groups reported for the formation in similar relative abundance. This taphonomic mode is characterized by disarticulation and skeleton dispersion patterns attributed to low-energy flowing water (Mancuso et al. 2014).

The mass-mortality assemblage preserves numerous small- and medium-bodied animals ( 8 to $18 \mathrm{~cm}$ skull length) in a single horizon with a large quantity of complete or partially articulated skeletons. This taphonomic mode is attributed to rapid burial (Mancuso et al. 2014).

Dicynodonts (Therapsids, Anomodontia) represent $9 \%$ of all individual specimens collected from the Chañares Formation, mainly attributed to the Chañares attritional assemblage, and are poorly represented by skulls and isolated post-cranial elements (Mancuso et al. 2014). Recently, a partially articulated dicynodont was recovered from the CF, the first specimen of a large taxon still articulated and well-preserved outside concretions and was attributed to the attritional assemblage stratigraphic levels. This material (CRILAR-PV 601) forms the basis of this study.

Decay, or decomposition, involves the breakdown of organic matter, as well as the creation of new organic compounds as a consequence of microbial metabolism and reproduction. There are numerous experimental studies that reveal sequences of change, transformation and loss of anatomical characters during decay (e.g., Bornemissza 1957; Payne 1965; Davis and Briggs 1998; Cambra-Moo et al. 2008; Sansom et al. 2013). The stages of decomposition are well documented in forensic studies and include fresh, bloated, active decay, advanced dry decay, and skeletal remains stages (Payne 1965). Paleontological studies suggest that very influential factors in the decay process are the presence of insects, temperature, and moisture around the carcass (Payne 1965; Davis and Briggs 1998; Carter et al. 2007; Cambra-Moo et al. 2008; Sansom et al. 2013).

The aim of this study was to conduct a detailed taphonomic analysis of the recently recovered dicynodont. The locality, the partial articulation, and the non-calcareous concretion situation make this worthy of particular study. This detailed taphonomic analysis revealed the activity of microorganisms in the decay processes during biostratinomic and diagenetic stages. Furthermore, this study produced a re-evaluation of the role of concretions in the preservation of this important fauna.

\section{GEOLOGICAL SETTING}

In Argentina, Triassic non-marine basins are mainly concentrated along what was the western Gondwana margin. Triassic sediment was deposited in continental rifts with asymmetric half-graben geometry (Legarreta 1992) formed by extensional deformation related to the pre-breakup of Pangea focused along northwest-trending Paleozoic sutures (Uliana and Biddle 1988). Most of the Triassic rift basins in northwestern Argentina record exclusively continental successions. They preserve one of the most globally important Triassic faunal and floral records with outstanding abundance and diversity of fossils.

The Ischigualasto-Villa Unión (IVU) Basin is a Triassic rift basin, characterized by a NW-SE orientated, elongated depocenter associated with the Valle Fértil Lineament (interpreted to be a Triassic normal fault). At present, outcrops are located along the border between the San Juan and La Rioja provinces. The succession consists of up to $4000 \mathrm{~m}$ of alluvial, fluvial, and lacustrine strata (Stipanicic 2002).The IVU Basin rests unconformably upon different Paleozoic deposits (Caselli 1998), and is 
separated by a regional unconformity from the fluvial conglomerates and sandstones of the Cretaceous-Cenozoic Cerro Rajado Formation (Caselli et al. 2001).

The red alluvial fan, ephemeral fluvial, and playa-lake successions of the Talampaya (Permo-Triassic, Gulbranson et al. 2015) and Tarjados formations correspond to the initial infill of the Triassic basin (Caselli 1998; Krapovickas et al. 2013). The Agua de la Peña (AP) Group unconformably overlies the Tarjados Formation. The AP Group consists of four formations: the Chañares, Los Rastros, Ischigualasto and Los Colorados (Mancuso 2005). The lower Carnian CF consists of tuffaceous sandstone and siltstone deposited in fluvial-lacustrine environments, as well as orthoconglomerate and paraconglomerate deposited in alluvial fans along the northwest margin of the basin (Rogers et al. 2001; Mancuso et al. 2014; Marsicano et al. 2015). The tuffaceous sandstone and siltstone of the CF is transitionally overlain by the deep lacustrine black shale and deltaic sandstone of the Los Rastros Formation (Mancuso and Caselli 2012). Fluvial sandstone, mudstone and tuff of the Ischigualasto Formation (Carnian-Norian, Martinez et al. 2011) unconformably overlie the lacustrine-deltaic deposits of Los Rastros Formation (Currie et al. 2009). The Los Colorados Formation (Norian, Kent et al. 2014) caps the Triassic succession, and is characterized by mudstone and sandstone red beds deposited in a moderate-sinuosity fluvial system (Caselli et al. 2001).

\section{MATERIAL AND METHODS}

The study material (CRILAR-PV 601) includes the fragmentary cranium, one tusk, one cervical vertebra, 17 dorsal vertebrae, 21 dorsal ribs, one complete scapula, another fragmentary scapula, one clavicle, one interclavicle, a sternum, and fragmentary indeterminate bones of a dicynodont collected from the structureless light-gray mudstone, $6 \mathrm{~m}$ above the silicified paleosol that marks the Tarjados-Chanares contact at the Río Gualo locality.

The bone histology and diagenetic features were analyzed through thinsections of dorsal ribs, which were processed following the techniques outlined by Chinsamy and Raath (1992), and Wilson (1994). These samples were studied under plane- and cross-polarized light using a petrographic microscope (BX 51-P Olympus). Histological terminology and definitions were taken from Francillon-Vieillot et al. (1990), de Ricqlès et al. (1991), and Reid (1996). The thin-sections also were used to analyze diagenetic features such as permineralization, fracturing and deformation.

Qualitative analyses of crystalline solids were performed in INTEQUI, UNSL-CONICET with a RIGAKUD-MAX IIIC diffractometer using a copper lamp operated with a nickel filter at $30 \mathrm{kV}, 20 \mathrm{~mA}$, scanning speed of $1.5 \%$ min., pitch reading of $0.05^{\circ}$ continuous. The samples analyzed correspond to bones and sedimentary rocks, ground and sieved to meet the $<200 \mu \mathrm{m}$ fraction (Fritsch Analisette). X-ray diffraction of the milled samples showed the presence of crystalline structures in all samples (Previtera et al. 2013, 2016).

Elemental composition of carbon-coated samples was obtained using a scanning electron microscope (SEM) JEOL JSM-6610 LV equipped with an energy-dispersive spectrometer (Thermo Scientific Ultra Dry Noran System 7) in MEBYM, IANIGLA-CONICET. We used an acquisition live time of $30 \mathrm{~s}$, nominal incident beam energy $E_{\mathrm{o}}=15 \mathrm{keV}$, and $10 \mathrm{~mm}$ working distance. Results provided are qualitative. The Proza Phi-Rho-Z algorithmic correction method (Bastin et al. 1986) was used to perform matrix correction. Map-scans were performed from the center of the bone through the bone-rock matrix interface and out to the edge of the rock. Weight percentage of major elements (C, O, F, Al, Si, P, K, Ca, Mn, Mg, $\mathrm{Fe}, \mathrm{Na}, \mathrm{S}$ ) were determined at points across the sample. The points were selected in order to include major cations for rock-matrix minerals (e.g., silicate, carbonate), commonly known enrichment constituents, major pore

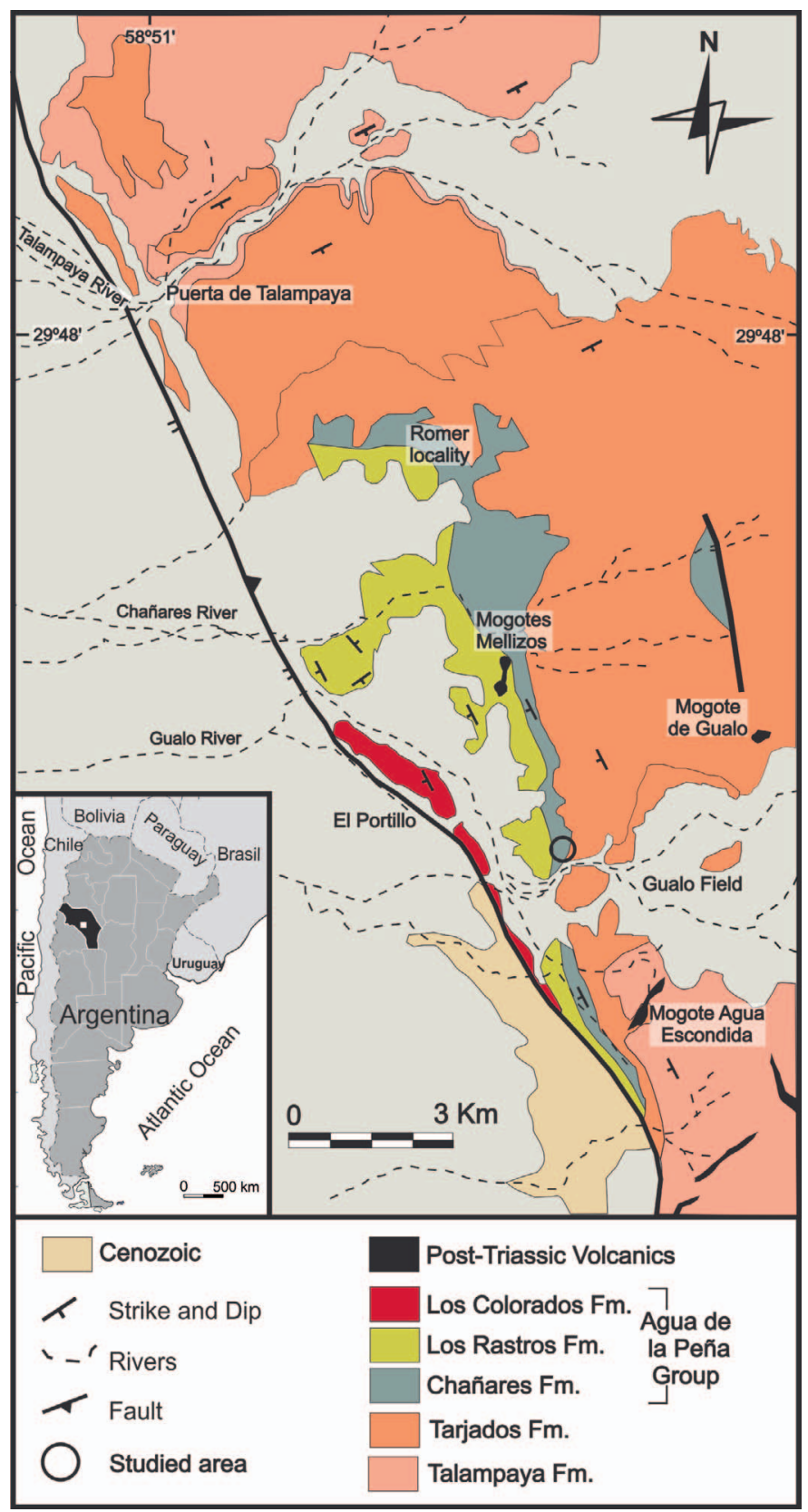

FIG. 1.-Geological map of the Río Chañares-Río Gualo area in the Talampaya National Park (La Rioja Province). Circle indicates the log section and the quarry area.

fillers (e.g., Fe, $\mathrm{Si}, \mathrm{Mn}$ ), and chemical compounds representing the original bone composition (e.g., carbonate, phosphate).

\section{CHAÑARES FORMATION PALEOENVIRONMENT}

In the Talampaya National Park (La Rioja Province) (Fig. 1), the Tarjados Formation paleotopography finishes with a silicified paleosol, on top (Figs. 2, 3) of which rests the CF (Mancuso 2005; Mancuso and Caselli 2012). The oldest layer of the CF comprises a light olive-gray, horizontally bedded to planar cross-bedded, fine-grained sandstone (Sh, Sp; Table 1, Figs. 2, 4A). This unit includes silicified root trace fossils, scattered 


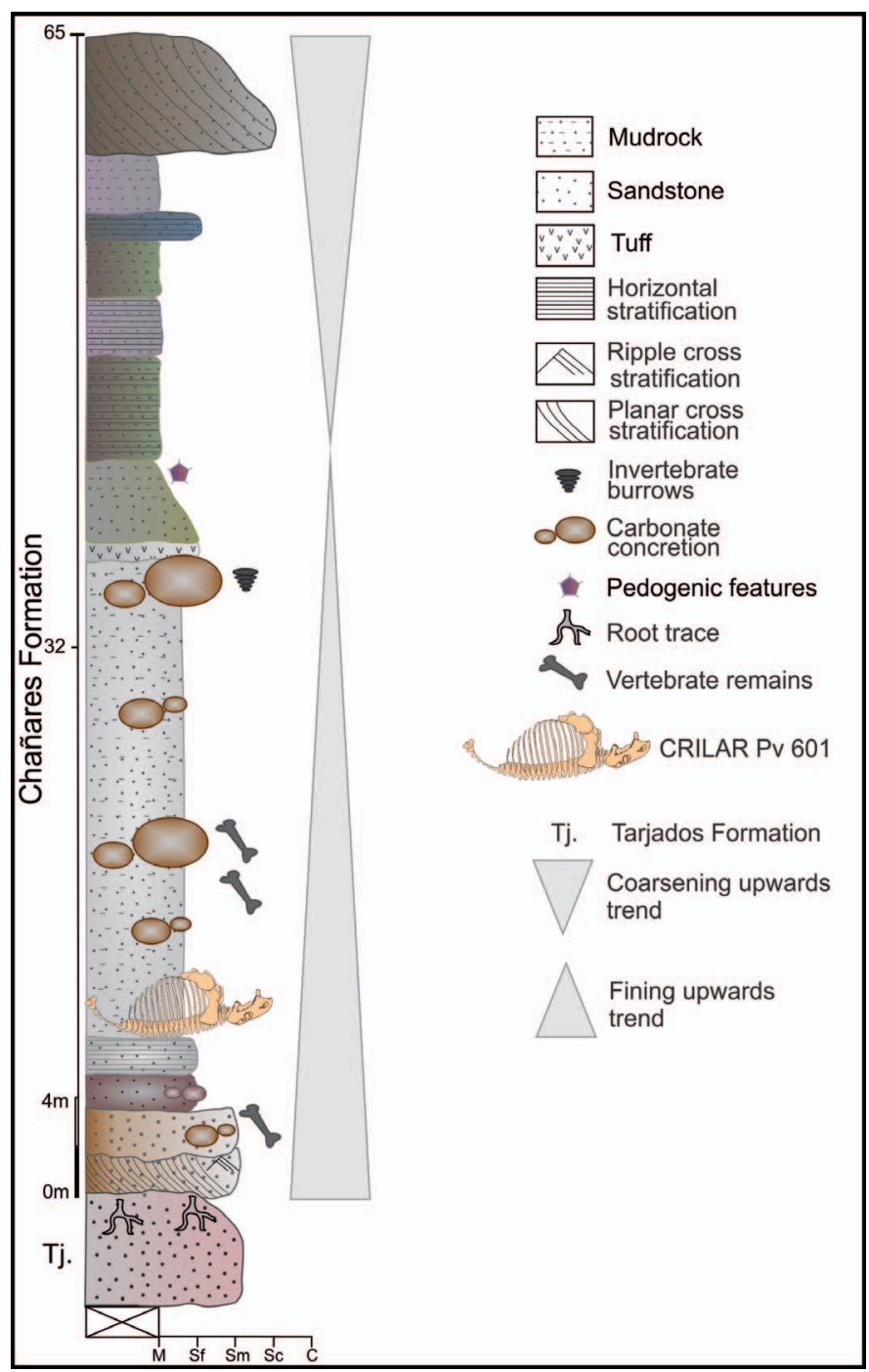

FIG. 2.-Log section of the Chañares Formation at the Río Gualo area.

pebbles, and locally abundant small, brown carbonate concretions (5-25 $\mathrm{cm}$ in diameter) (Fig. 4B). The following layer above is dominated by gray fine-grained sandstone and siltstone preserving few embedded vertebrate remains (Figs. 2, 4B).

The next $35.5 \mathrm{~m}$ of the CF consist of laterally persistent, tuffaceous, bluish-gray claystone, siltstone, and silty sandstone (TFm; Table 1, Fig. 4C). The beds are internally structureless with 'popcorn-like' weathering, typically associated with a high bentonite clay content (e.g., Terry et al. 1998) and abundant brown calcareous concretions (Fig. 4C). There are small concretions with maximum diameter of $0.4 \mathrm{~m}$ and large concretions that are approximately $2 \mathrm{~m}$ in diameter. The small concretions are randomly distributed in the lower $20 \mathrm{~m}$ of the formation, whereas the large concretions occur in two discrete horizons (see arrow in Fig. 4B). The lower large concretion level is located $15 \mathrm{~m}$ above the base of the formation and the upper large concretion level about $10 \mathrm{~m}$ higher at the top of a mudrock unit in which vertical meniscate burrows $(1 \mathrm{~cm}$ diameter $)$ are also found (Fig. 4D). Thin-sections of the large concretion matrix show grains of quartz, plagioclase and corroded lithic fragments with cuspate glass shards that have been altered to calcite, and iron oxides (Rogers et al. 2001).

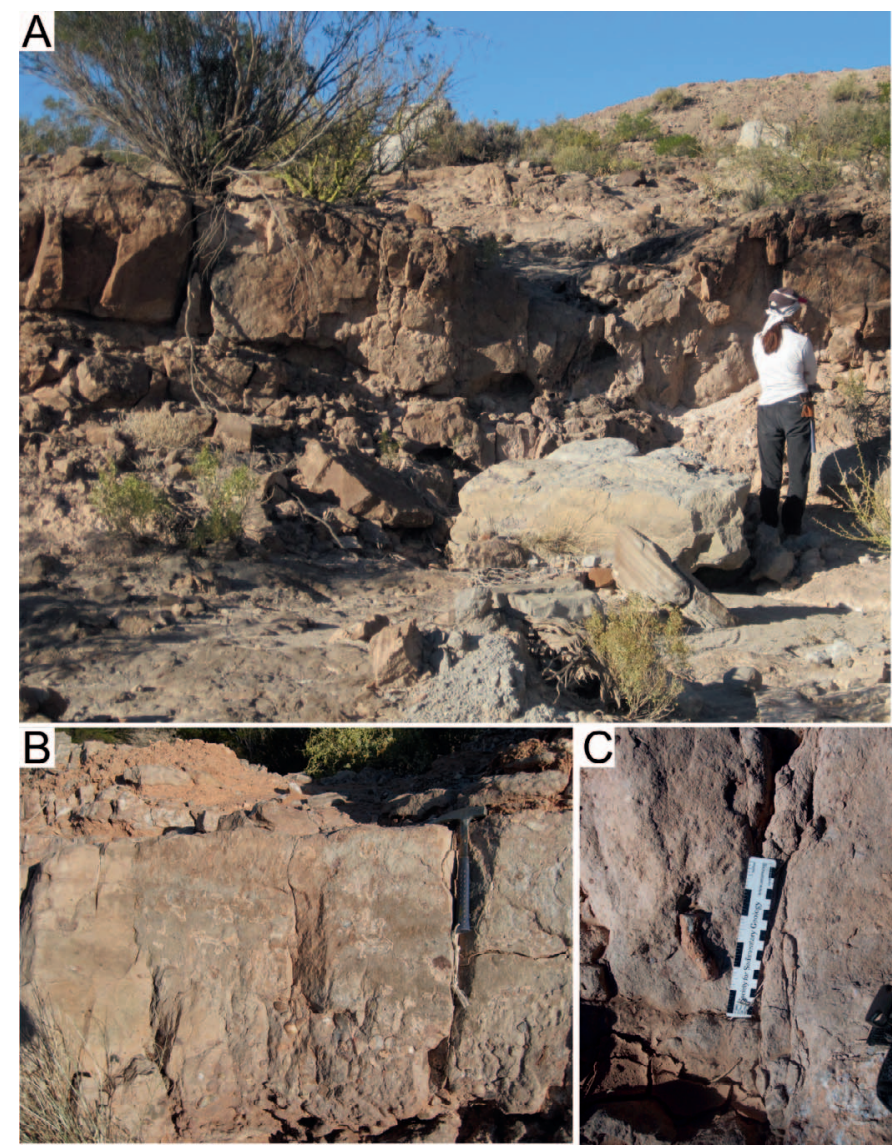

FIG. 3.-A) Outcrop photograph from the paleotopography on the top of Tarjados Formation, notice person for scale. B, C) Detail of the Tarjados Formation paleosol characterized by intense silicification and pedogenic features, such as vertical and horizontal tubules that branch and decrease in diameter towards the base of the strata.

Lithology, sedimentary structures and geometry (Table 1) suggest that the tuffaceous sandstone was deposited by river channels, with the majority of bedload sedimentation in the fluvial system associated with the influx of pyroclastic sediment (Rogers et al. 2001; Mancuso 2005; Mancuso et al. 2014). The tuffaceous claystone, siltstone and silty sandstone were deposited on a thick pedogenically modified floodplain (Rogers et al. 2001; Mancuso 2005; Mancuso et al. 2014) where the calcareous concretions are interpreted to be of pedogenic origin (Ashley and Driese 2000; Retallack 2005).

Capping the CF massive laterally persistent, light-gray and pale-olive, thinly laminated claystone and siltstone (Fm, Fl; Table 1) predominate (Fig. 4E). This facies also displays 'popcorn-like' weathering, as well as randomly dispersed sub-vertical invertebrate burrows (10-12 cm long and $0.8 \mathrm{~cm}$ wide), with meniscate infilling, assigned to the ichnogenus Taenidium (Rogers et al. 2001). Up to $5 \mathrm{~m}$ thick, lobate-shaped, yellowish gray, parallel-stratified to planar cross-bedded sandstone is interbedded within the Fl package.

The fine-grained lithologies and sedimentary structures support the interpretation that these mudrocks were deposited by suspension settling in a lacustrine environment (Rogers et al. 2001; Mancuso 2005; Mancuso et al. 2014). The coarser-grained deposits described are interpreted as reflecting the onset of progradation.

The extraordinary record of tetrapod fossils comprising the Chañares fauna comes from the lower $15 \mathrm{~m}$ of the formation. These skeletal remains 


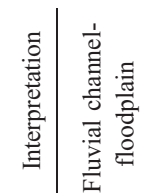

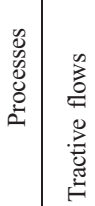

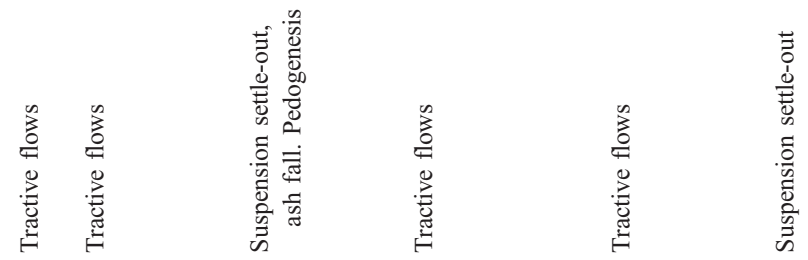

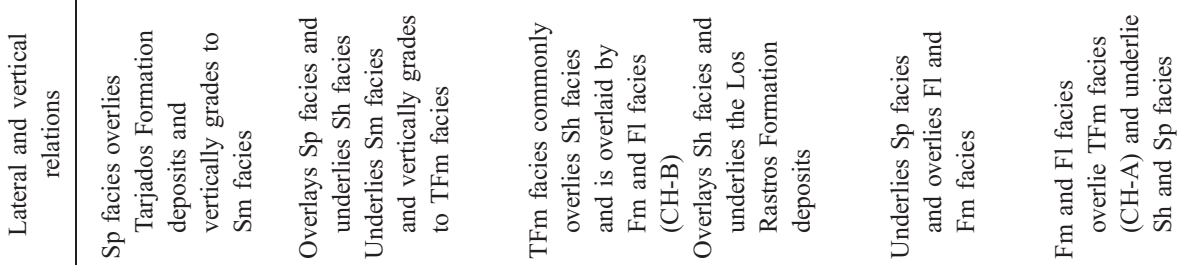

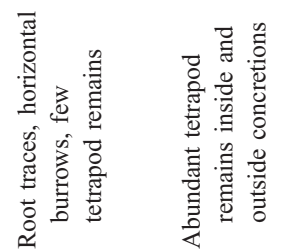

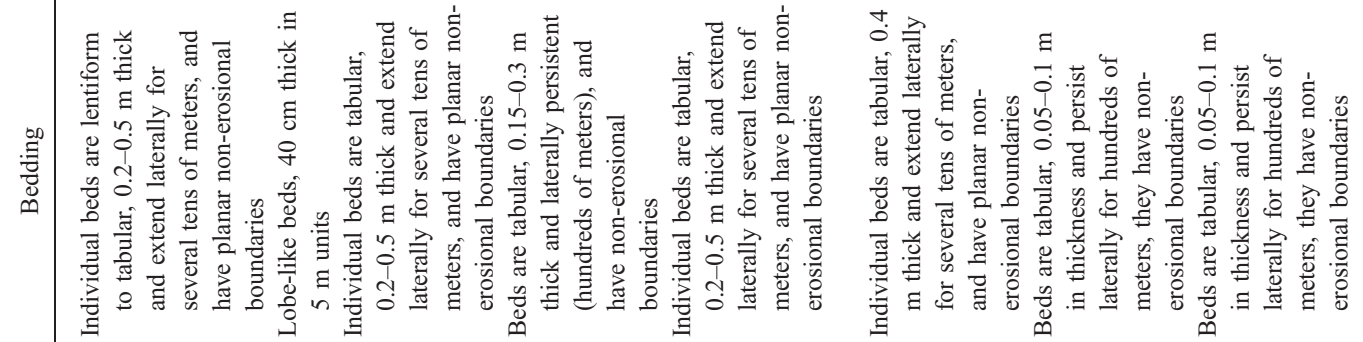

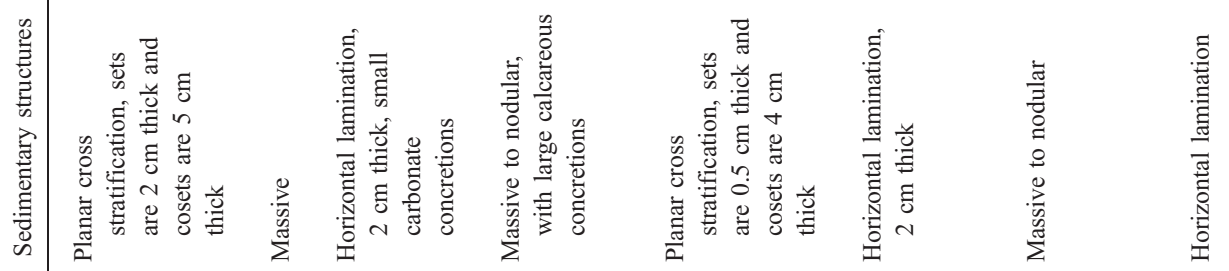

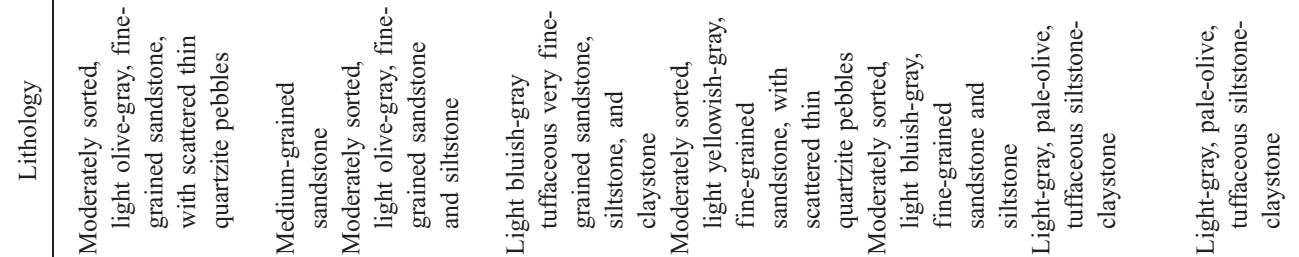

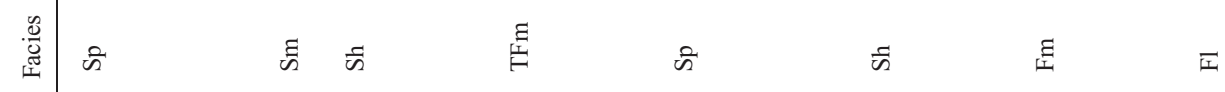

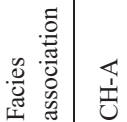




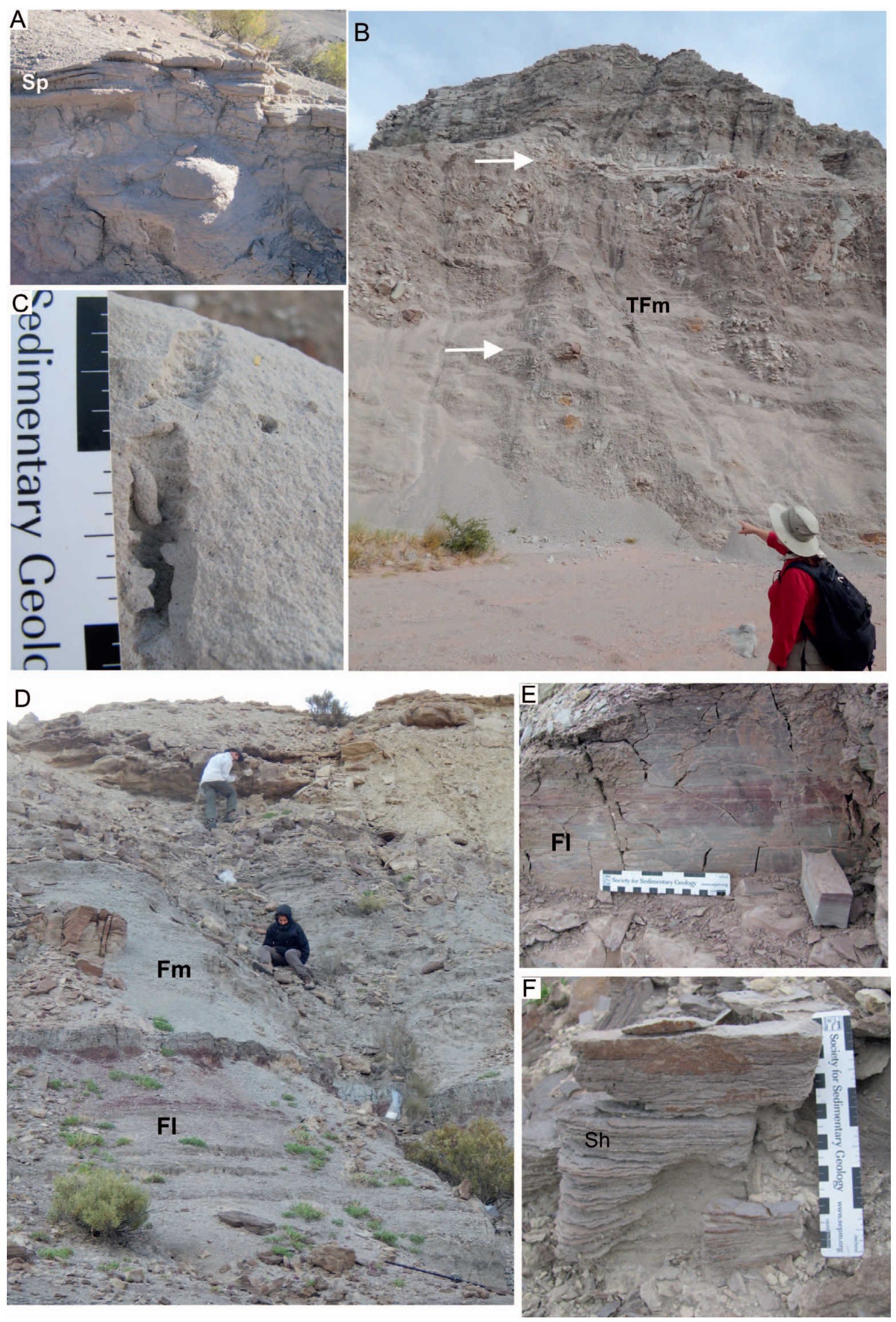



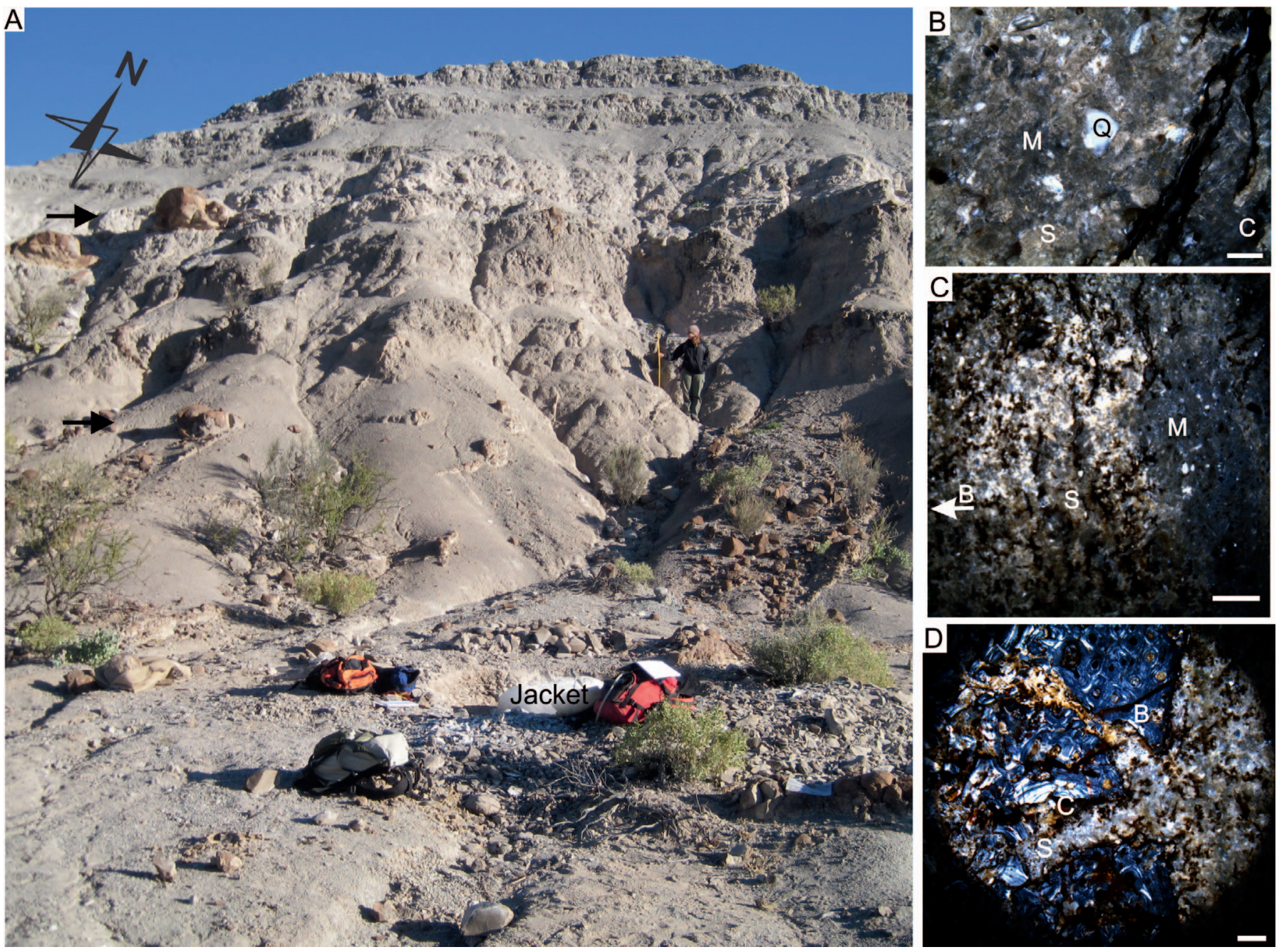

FIG. 5.-A) Outcrop photograph of the quarry just above the contact between the Tarjados and the Chañares formations, notice person for scale. Two levels of large brownish concretions (arrows) can be seen in the photograph. On the floor the jacket of CRILAR-PV 601. B) Cross-section microphotograph of the host rock. Calcite rich matrix (micrite $=\mathrm{M}, \mathrm{spar}=\mathrm{S}$ ) with disperse siliciclastic grains, mainly subangular quartz $(\mathrm{Q})$. Scale bar $=100 \mu \mathrm{m}$. C) Cross-section microphotograph of the host rock. Fringe bone (B, arrow)-matrix area (Rock-Bone Interface Sample) where spar cement (S) coating the bone and reddish-brown clays (C) have been identified, distally the micrite fringe $(\mathrm{M})$ can be seen. Scale bar $=50 \mu \mathrm{m}$. D) Cross-section microphotograph from the fragmented bone $(\mathrm{B})$ where spar $(\mathrm{S})$ and clay $(\mathrm{C})$ inclusions can be seen. Scale bar $=$ $50 \mu \mathrm{m}$.

are found directly entombed in the tuffaceous clay-siltstone or in concretions (both small and large) of the lower horizon (Mancuso et al. 2014) within fluvial facies and mainly pedogenically modified floodplain facies.

During the Triassic period the paleogeographic configuration of the land masses gathered in Pangea caused particular climate conditions of a megamonsoon system and extreme seasonality (Kutzbach and Gallimore 1989; Parrish 1993). For Southwest Gondwana, phytogeographic provincialism is characterized by the Ipswich microflora during the Middle and Late Triassic and developed in an Extratropical Area with inferred subtropical arid climate conditions (Artabe et al. 2003). For the late Carnian, in the IVU Basin, the paleosol types and their characteristics and geochemistry allow for the identification of a seasonal pattern of humidarid-humid conditions for the Ischigualasto Formation (Tabor et al. 2006).

\section{VERTEBRATE TAPHONOMY}

Host Rock.-The CRILAR-PV 601 specimen was found $6 \mathrm{~m}$ above the Tarjados-Chañares formations contact (Fig. 5A) embedded in laterally persistent, structureless, light-gray mudstone (TFm, Fig. 4B), interpreted as pedogenically modified floodplain (Mancuso 2005; Mancuso et al. 2014).

Thin-sections of the host rock in the areas surrounding the bone remains show a mainly detrital composition with angular quartz clasts (Fig. 5B). However, in the areas adjacent to the bones, the composition of the matrix is predominantly calcite (Fig. 5C). At the bone-matrix contact, a $500 \mu \mathrm{m}$

Fig. 4.-A) Detail of the fine-grained sandstone with planar cross-bedded (Sp) of the fluvial facies. B) Outcrop photograph from the lower section (TFm facies) of the Chañares Formation (CF). The large concretion levels of the TFm facies are pointed out (arrows). Person for scale. C) Detail of a burrow found in the CH-A facies, notice the meniscate interior of the tube. D) Outcrop photograph from the upper section of the CF where the CH-B facies (Fm, Fl) was described. Person for scale. E) Detail of the thinly laminated siltstone to claystone (Fl) of facies $\mathrm{CH}-\mathrm{B}$. F) Detail of fine-grained sandstone with horizontal stratification (Sh) of the $\mathrm{CH}-\mathrm{B}$ facies. 

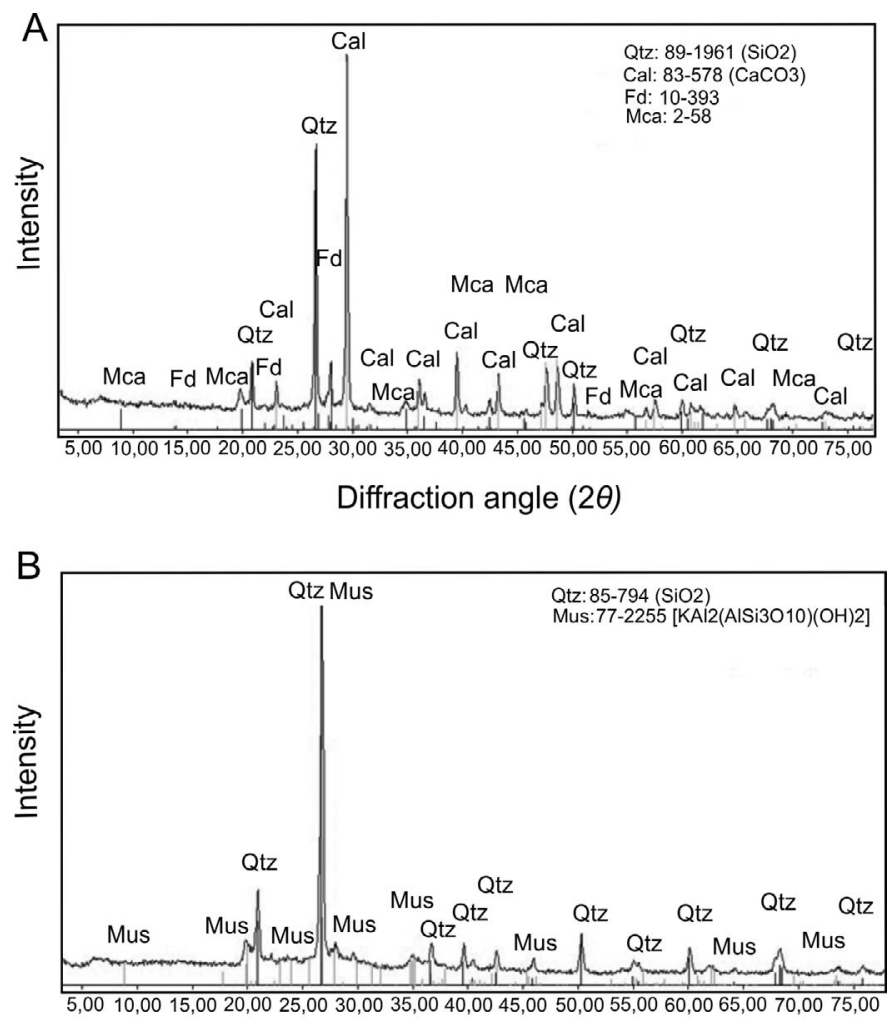

Diffraction angle $(2 \theta)$

FIg. 6.-A) X-ray diffraction data of the Rock-Bone Interface Sample. B) X-ray diffraction data of the Rock Sample.

thick layer of microspar and sparite coat the bone surface (Fig. 5D), and more distally, a halo of micrite with a clotted texture is recognized (Fig. $5 \mathrm{E})$. Associated with the calcareous bone-matrix, fringe and infilling fractures penetrate through the bone surface, with opaque, reddish-, darkbrown or black clays (Fig. 5D) and quartz clasts. X-ray diffraction analysis of the mudstone in contact with the CRILAR-PV 601 bone (referred to as "Rock-Bone Interface Sample" in Fig. 6) shows the predominance of quartz and calcite along with some principal phases probably feldspar and mica, most likely muscovite (Fig. 6A). In contrast, XRD analysis of the rock matrix more distal to the skeleton ("Rock Sample" in Fig. 6) showed the presence of crystalline phases of quartz and illite (muscovite type) (Fig. $6 \mathrm{~B}$ ). This result expands the previous XRD analysis, showing montmorillonite to be the major clay type in this facies (Rogers et al. 2001).

Completeness.-The CRILAR-PV 601 specimen comprises $40 \%$ of the elements of a dicynodont skeleton from the Chañares Fauna. Skeletal elements included the fragmentary cranium, one tusk, one cervical vertebra, 17 dorsal vertebrae, 21 dorsal ribs, one complete scapula and another fragmentary scapula, one clavicle, one interclavicle, a sternum, and fragmentary indeterminate bones (Fig. 7). The pelvic girdle (ilium, ischium, pubis) and limb bones (humerus, ulna, radius, femur, tibia, fibula, metacarpals, phalanges) are missing (Fig. 7).

Articulation Degree.-The specimen is partially articulated (Figs. 7, 8 ), all the vertebrae and ribs are articulated, and the skull is slightly rotated. The scapulas, clavicle, interclavicle, and sternum are almost in life position (Figs. 7, 8).

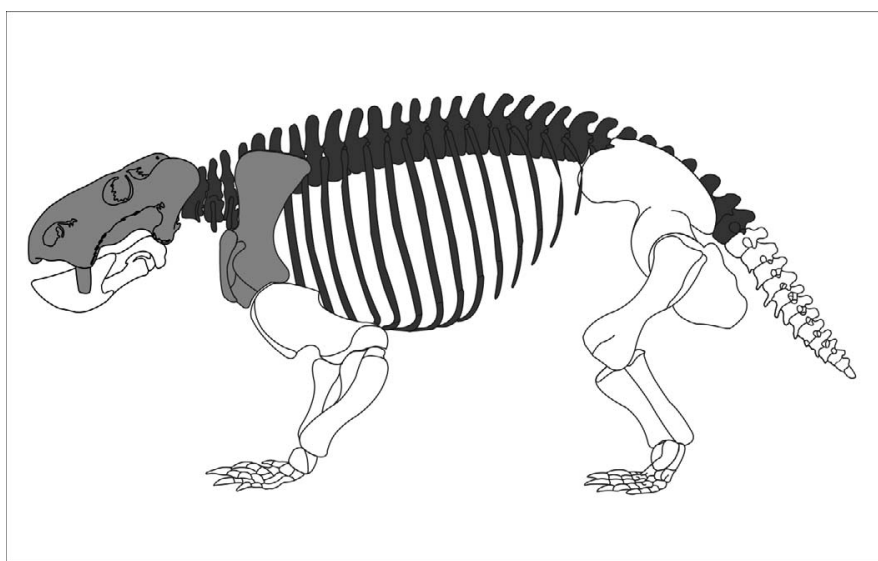

FIG. 7.-Dicynodont skeleton with the elements recovered. The dark gray represents the bones fully articulated and the light gray represents the bone slightly displaced.

Orientation and Attitude.-The CRILAR-PV 601 skeleton was preserved lying horizontally with the ventral-side up. The articulated vertebral column has been curved into a pronounced V-shape $\left(\sim 70^{\circ}\right.$ angle $)$ (Fig. 8). The anterior portion (skull and cervical and part of dorsal vertebrae) of the skeleton shows a general $\mathrm{N}$ trend and the posterior portion (part of a dorsal vertebra) shows an ENE trend. The curvature occurs between dorsal vertebrae number 9 and 10, otherwise the vertebrae are in natural articulation (Fig. 8). The skull is rotated out of in-vivo position (Fig. 8) and the ventral bones and mandible are missing (Fig. 9A). The scapulas are slightly displaced and the clavicle and interclavicle are also slightly displaced from life-position. The ribs are articulated in life-position (Fig. 9B).

Post-Mortem Modification.-The bones show superficial modifications in contrast to the excellent preservation of the majority of the Chañares fossils included in the mass-mortality assemblage (Mancuso 2005; Mancuso et al. 2014). Longitudinal and transverse fractures are observed on the external bone surfaces (Fig. 9). The longitudinal fractures are cemented, while the 'open' transverse fractures are non-cemented. The presence of fine cracking, the absence of flaking of external laminar bone, exposure of fibrous bone, and deep cracking suggest Stage 1 weathering (Behrensmeyer 1978; Fiorillo 1988). The bone surfaces display moderate corrosion with greater cracking and corrosion on the skull than the bones located in lower portion in the assemblage (Fig. 9A, 9D).

Histological Description.-The thin-sections of the ribs display a centrally located medullary cavity surrounded by an outer compact cortex. The external cortex on the peripheral region is composed of parallelfibered bone tissue containing simple canals, with multiple lines of arrested growth (LAGs) (Fig. 10A). The inner cortex comprises fibrolamellar bone tissue with primary osteons longitudinally oriented and embedded in a woven bone matrix. (Fig. 10A, 10B). The perimedullary region shows secondary remodeling with development of secondary osteons and large resorption cavities (Fig. 10C). The extensive secondary reconstruction in the ribs is possibly due to haemopoesis (Ray et al. 2010). Large cancellous spaces and extensive networks of bony trabeculae indicate endosteal deposition within the medullary cavity (Fig. 10D).

Bone Diagenesis.-The diagenetic processes affecting the microstructure of the ribs were permineralization (infiltration of mineral-bearing solutions into pores in skeletal tissue) and substitution. The ionic substitution of hydroxyapatite $\left[\mathrm{Ca}_{5}(\mathrm{PO} 4)_{3}{ }_{3}(\mathrm{OH})\right]$ by francolite $\left[\mathrm{Ca}_{5}\right.$ 

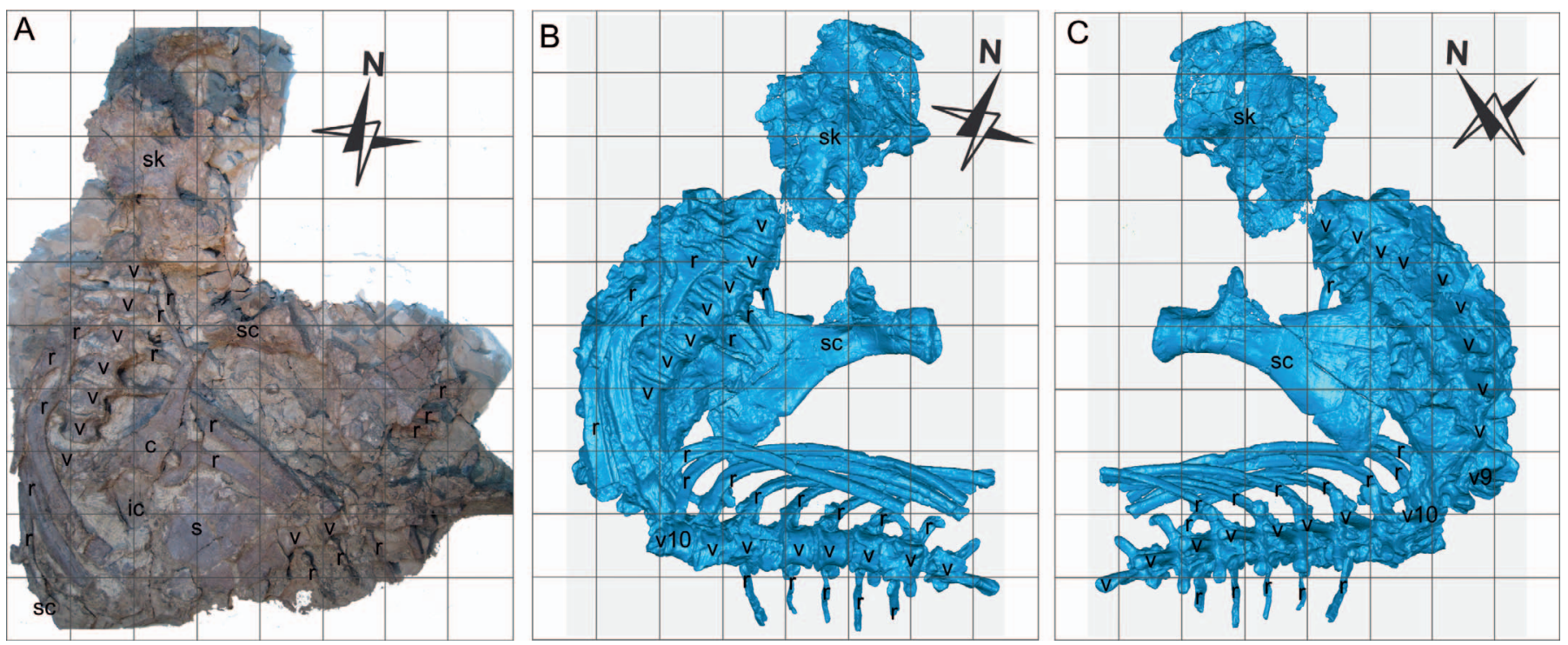

FIG. 8. - CRILAR-PV 601 skeleton. A) General view of the skeleton showing the ventral-up attitude and the degree of articulation. B) 3D model in ventral-up attitude of skeleton bones of CRILAR-PV 601, based on reconstructions from computed tomography data. C) 3D model in dorsal-up attitude of skeleton bones of CRILAR-PV 601, based on reconstructions from computed tomography data. Abbreviations: $\mathrm{sk}=$ skull; $\mathrm{v}=$ vertebra; $\mathrm{r}=\mathrm{rib} ; \mathrm{sc}=\mathrm{scapula} ; \mathrm{c}=$ clavicle; ic $=$ interclavicle; $\mathrm{s}=\mathrm{sternum}$. Scale box $=5 \mathrm{~cm}$.

$\left.\left(\mathrm{PO} 4, \mathrm{CO}_{3}\right)_{3}(\mathrm{~F})\right]$, a carbonate-rich type of fluorapatite, involves replacing hydroxyl group $(\mathrm{OH})$ by fluorine (F) (Lucas and Prévôt 1991). X-ray diffraction analysis showed the presence of several crystalline phases, where the fluorapatite appears as the main signal in the diffractogram. Other minor phases are coincident with calcite, quartz and lipscombite. The negligible presence of lipscombite may be due to the wide availability of phosphates in the sedimentary environment (Fig. 11A).

Analysis of thin-sections shows well-preserved bone microstructure composed of collophane (fluorapatite). The isotropic fluorapatite, confirmed by XRD, is recognized for being colorless in plane-polarized light, and has weak birefringence in bone tissue structure in cross-polarized light (Mackenzie and Guilford 1980). The external cortex displays parallelfibered bone with simple canals filled by iron oxides (Fig. 11B). The lithostatic pressure caused a system of fractures to be filled by infiltration of iron oxides that cut the vascular canals (Fig. 11B-11D). The inner cortex shows primary and secondary osteons filled by iron oxides and calcium carbonates (Fig. 11C). Within the osteons, there is a rim of fibrous calcite, and little black opaque minerals (Fig. 11D). The perimedullary region displays fractures cemented by microcrystalline calcite, and associated with iron oxides patches likely of hematite or magnetite (Fig 11E). Medullary region shows endosteal trabeculae and cancellous spaces cemented by calcite and iron oxides patches imposed onto the bone tissue (Fig. 11F).

SEM-EDX.-We performed image and maps in the thin-section of the CRILAR-PV 601 dorsal rib to monitored trends in elemental distributions. The EDX recognized $\mathrm{C}, \mathrm{O}, \mathrm{F}, \mathrm{Al}, \mathrm{Si}, \mathrm{P}, \mathrm{K}, \mathrm{Ca}, \mathrm{Mn}, \mathrm{Mg}, \mathrm{Fe}, \mathrm{Na}$, and $\mathrm{S}$ elements, which were mapped to show their qualitative distribution patterns. The major elements include $\mathrm{C}, \mathrm{O}, \mathrm{Al}, \mathrm{Si}, \mathrm{P}$, and $\mathrm{Ca}$, whereas the minor are $\mathrm{F}, \mathrm{Mn}, \mathrm{Mg}, \mathrm{K}, \mathrm{Fe}$, and $\mathrm{Al}$. Three areas were illustrated with the combination of the informative elements $(\mathrm{Si}, \mathrm{P}, \mathrm{Ca})$ to explain the role of bone decomposition and the interaction of bone and host rock. It is possible to see a clear limit between bone and matrix in the SEM image and EDX maps. $\mathrm{P}$ is mainly concentrated in the bone; however, there is a very low concentration and a homogeneous distribution in the rock (Fig. 12). Ca shows a homogeneous distribution in bone and rock, although displaying a higher concentration in the bone and a lower concentration in the most distal part of the rock (Fig. 12). Si and Al interpreted as the sediment of the mudrock matrix. $\mathrm{Si}$ is more concentrated in the rock opposite to P distribution (Fig. 12). In the bone, $\mathrm{Si}$ is mainly located in the infilling points. In general $\mathrm{Al}$ shows a similar distribution to $\mathrm{Si}$ (Fig. 12).

\section{PALEOBIOLOGY}

The CRILAR-PV 601 skeleton is identified as a tusked dicynodont based on the morphology of skull, canines, and scapula. A full morphological and taxonomic description is underway and will not be presented in this report.

The specimen was found alone, but it is widely accepted that the large Triassic dicynodonts were gregarious (King 1990; de Oliveira Bueno et al. 2011; de Oliveira Bueno 2012) with evidence, in the same succession, of social behavior (Marsicano et al. 2010; Mancuso et al. 2014).

The skeleton belongs to an adult individual inferred from gross skeletal morphology, relative size, and microstructure (Ray and Chinsamy 2004). The presence of peripheral parallel-fibered bone and fibrolamellar bone, growth marks, extensive secondary reconstruction, and endosteal bone deposition observed in rib transverse section also corresponds to that of an adult specimen. This ontogenetic stage inferred here is comparable with Growth stage III: size class C-adults ( $>60 \%$ adult size) described for Wadiasaurus (Ray et al. 2010). The overall bone microstructure in this growth stage suggests an initial fast growth followed by a decrease in the active bone growth rate and permanent slowing down of overall growth (Ray et al. 2010). This is all consistent with our current knowledge of dicynodont growth patterns.

\section{TAPHONOMIC HISTORY}

The histological features of the CRILAR-PV 601 individual indicate that it is probably a young adult, so the likely cause of death would have been predation, or disease (Fig. 13). The bones do not display tooth marks that would evidence predation or vertebrate scavenging. However, the missing hindquarter could possibly have been scavenged (Lyman 1994) (Fig. 12). The persistence of articulated elements in the skeleton suggests that the small-scale soft tissue removal was performed by invertebrates and 


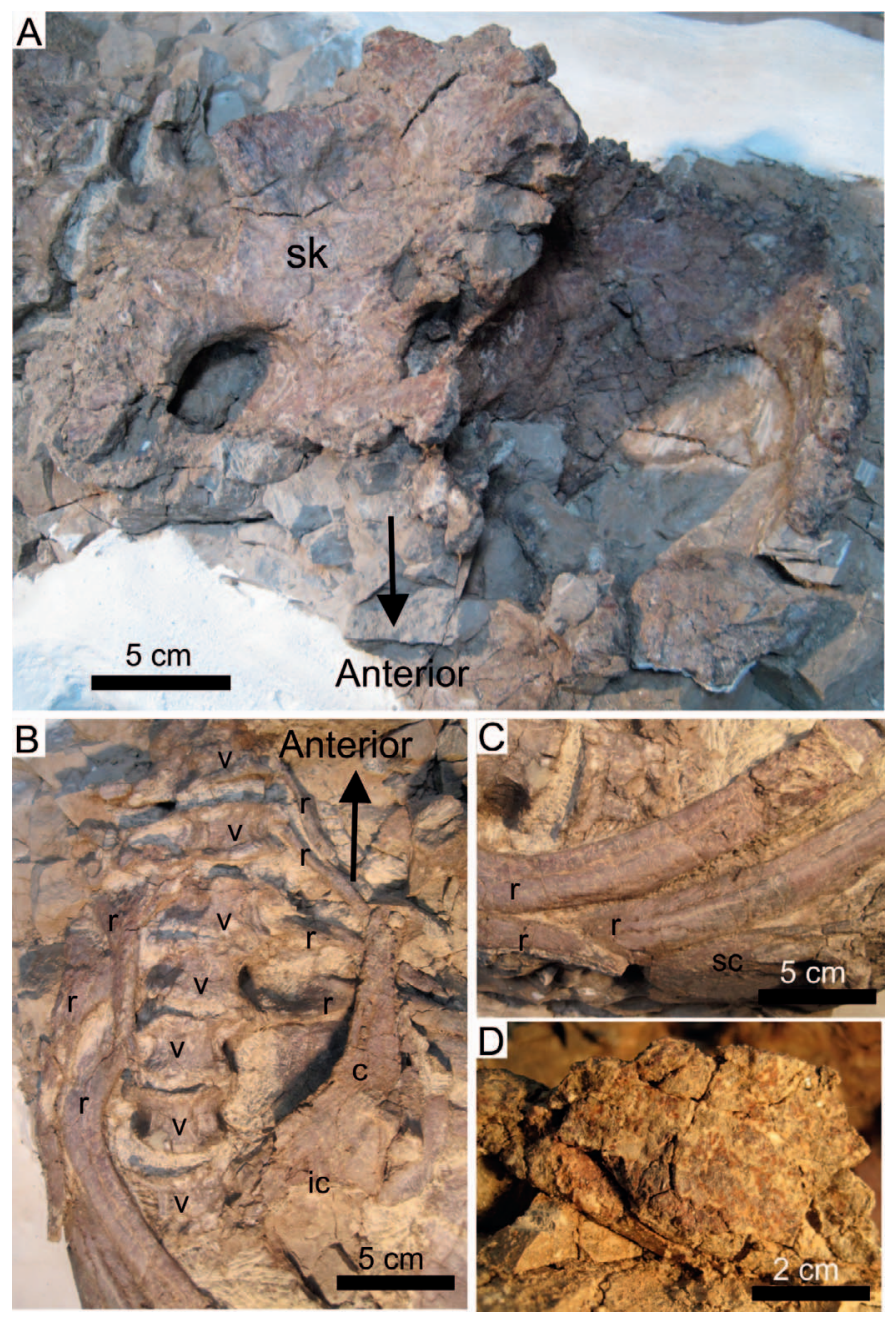

FIG. 9.- Large non-mammalian therapsid skeleton. A) Detail of skull in rotated position. B) Detail of vertebrae and ribs in life-position. C) Detail of superficial modification on ribs. E) Detail of corrosion on skull. Abbreviations: sk $=$ skull; $\mathrm{v}=$ vertebra; $\mathrm{r}=\mathrm{rib} ; \mathrm{sc}=$ scapula; $\mathrm{c}=$ clavicle; ic = interclavicle; $\mathrm{s}=$ sternum.

bacteria (Lyman 1994). The decomposition of the soft tissue by invertebrate scavengers and decay agents may have been responsible for the slight displacement observed in some bones of this skeleton (Fig. 8).

The CRILAR-PV 601 specimen was included in the attritional mortality taphonomic pathway proposed for the Chanares ecosystem (Mancuso et al. 2014) based on taphonomic features and the stratigraphic position. Mancuso et al. (2014) documented that the remains included in this pathway show some degree of sorting, and the bone accumulations represent mainly Voorhies Groups III, and also evidence interaction between the organic remains and the entombing sediment. It was proposed that the remains included in this pathway would have been removed by low-energy currents and low- and medium-mass skeletal elements were transported into the basin and consequently entombed. Contrary to other specimens in the attritional assemblage, CRILAR-PV 601 lacks evidence of hydraulic transport, since the low- and medium-mass skeletal elements are entombed together with high-mass skeletal element, such as the skull. It would seem more likely then, that the loss of the limbs were evidence of being a food supply rather than lost in transport.

Another feature reported is the higher degree of corrosion observed on the upper surfaces of some bones of the CRILAR-PV 601carcass. The explanation for corrosion is related with the microenvironment chemistry
(Lyman 1994; Downing and Park 1998) and given that the upper surface of the bones are more corroded, it is reasonable to assume that this feature is associated with the subaerial exposure. A prolonged, aerobic exposure period of the upper part of the carcass could have allowed aerobic decay organisms to create a microenvironment (Fig. 13) that promoted the corrosion of exposed bones (Lyman 1994; Downing and Park 1998; Fiorillo 1998).

While it was exposed on the floodplain surface, it was probably not only scavenger activities that affected the carcass. Bone weathering can also be important (Fig. 13). The CRILAR-PV 601 skeleton displays mainly longitudinal fractures and minor cracking characteristic of Stage 1 weathering (Behrensmeyer 1978; Fiorillo 1988), consistent with a relatively short time of subaerial exposure prior to burial. Despite many attempts to correlate weathering stages with periods of exposure, there are too many variables that limit a direct temporal correlation (Lyman 1994; Eberth et al. 2007). We can only assume from the degree of desiccation that the skeleton passed a minimum of several weeks to a maximum of three years exposed in the floodplain surface before being completely entombed (Behrensmeyer 1978; Fiorillo 1988).

Complete burial is one of the most important taphonomic processes in fossil preservation, and this is controlled by several processes (Lyman 1994). The time interval between episodes of sedimentation and the thickness of sedimentary increments are the major determinants of the rate of entombment and the intensity of the biostratinomic process that affected the cadaver. Thus, the increased corrosion of the bones located at the top of the carcass could suggest that the entombment was progressive and prolonged (Fig. 13). The lack of sedimentary structures in the host matrix suggests constant prolonged sedimentation rather than an episodic event. Subsurface taphonomy includes being physically disrupted by roots (pedogenesis) and burrowing animals and chemically affected by the permeability of the sediment and the chemistry of the groundwater. These factors are included in early diagenetic processes, and will be discussed later in this contribution. To summarize the biostratinomy, the articulated skeleton with minor macroscopic bone modification suggests a relatively early burial, however the local subaerial weathering reveals a relatively slow burial process (Fig. 13).

The carcass is finally entombed in a water-saturated environment (reduced Fe) with light-colored and fine-grained sediments that formed part of a floodplain facies. The presence of pedogenic calcareous concretions and carbonate cement suggests that the entombment environment contained $\mathrm{CaCO}_{3}$ rich groundwater possibly linked to percolation of rainwater through volcanic sediments. The presence of clotted micrite around the bones suggests an organic origin possibly link to biologically induced precipitation of calcium carbonate by bacteria involved in organic matter decay (Fig. 13) (Dupraz et al. 2009). Most likely heterotrophic bacteria played a significant role in $\mathrm{C}$ recycling by organic matter oxidation (Petrisor and Decho 2004; Dupraz et al. 2009). According to Dupraz et al. (2009), these activities liberate $C_{\text {inorg }}$ that in addition to $\mathrm{C}_{\text {org }}$ directly contributes to carbonate precipitation. The microspar and spar are secondary cements likely formed by dissolution and re-precipitation of the primary micrite in a Ca-rich microenvironment with $\mathrm{CO}_{3}$ supply from the decomposition processes. However, contrary to what expected, the calcite cements are observed in contact with the bone surfaces and the micrite is identified more distally but still in proximity to the bone. More distal to the skeleton, the "Rock Sample" evidenced the absence of calcite. This probably indicates that the alteration of bones involved dehydration and these fluids might have dissolved the micrite in the innermost layer of the matrix, while the original composition was retained more externally.

CRILAR-PV 601 carcass does not display evidence of pedogenesis (physically disrupted by roots and burrowing animals) but the thin-sections of the bones display other diagenetic processes including four different permineralization events (Figs. 11B-11F, 13): (1) a first event of iron oxide 

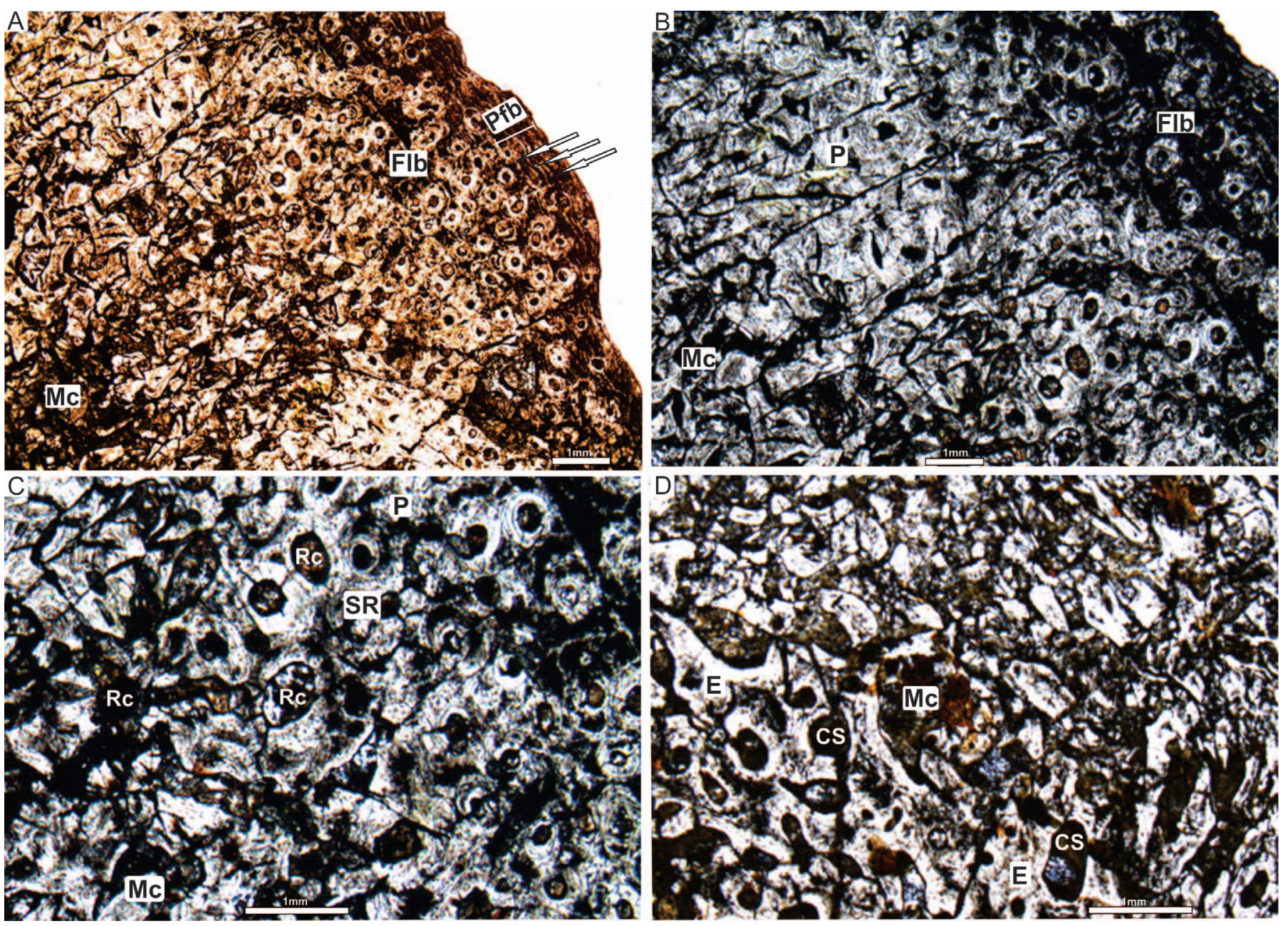

FIG. 10.-Bone microstructure of the large non-mammalian therapsid rib in thin-sections. A) External cortex showing parallel-fibered bone (bracket) with LAGs (arrows), and inner cortex with fibrolamellar bone. B) Fibrolamellar bone with primary osteons and perimedullary region exhibiting secondary osteons. C) Perimedullary region shows secondary remodeling and resorption cavities. D) Medullary cavity with cancellous spaces and endosteal trabeculae. Abbreviations: Pfb = parallel-fibered bone; Flb = fibrolamellar bone; $\mathrm{P}=$ perimedullary region; $\mathrm{SR}=$ secondary remodeling; $\mathrm{Rc}=$ resorption cavity; $\mathrm{Mc}=$ medullary cavity; $\mathrm{E}=\mathrm{endosteal}$ trabeculae; $\mathrm{Cs}=$ cancellous space. Photomicrographs in plane-polarized light. Scale bar $=1 \mathrm{~mm}$.

cementation in osteons, vascular canals, and fractures; (2) fracturing and brittle deformation in vascular canals, trabeculae, and pore spaces; (3) a stage of calcite precipitation in vascular canals, cancellous spaces, and longitudinal fractures; and (4) final infiltration of iron oxides precipitated in the medullary tissue. The transverse fractures observed in the bones were produce after mineralization of the bone during the post-burial stages, and the absence of infill in the transverse fractures indicates rapid exhumation (Fig. 13).

\section{DECAY AND MICROENVIRONMENTS}

When small organisms (such as insect larvae) and micro-organisms (such as fungi and bacteria) use a vertebrate carcass as a food source, this results in bioerosion, decomposition, or decay (Lyman 1994). Bone decay micro-organisms leave evidence of their action in the bones, in the form of tunnels or surface trails and grooves (e.g., Kitching 1980; Piepenbrink 1986; Hanson and Buiskra 1987; Rogers 1992; Lyman 1994; Trueman et al. 2004; Pirrone et al. 2014). Soft tissue decay micro-organisms leave a chemical signature of partial or total consumption of the soft tissue (Allison and Briggs 1991; Lyman 1994). CRILAR-PV 601 lacks evidence of bone decay; however, we can report chemical evidence of pre- and postburial soft tissue decay of the carcass.

Breakdown of the soft tissues is initiated by autolysis before bacteria gained access to the deeper tissues. On death, colonization of the carcass occurs from bacteria present within the living animal and external bacteria entering the body after death through orifices and trauma (e.g., Bornemissza 1957; Payne 1965; Davis and Briggs 1998; Carter et al. 2007; Sansom et al. 2013) Some authors propose that the rate of decomposition is ultimately controlled by temperature due to its enhancement or inhibition of insect and microorganism activity (Carter et al. 2007). Experimental cadaver decomposition studies (e.g., Bornemissza 1957; Payne 1965; Davis and Briggs 1998; Cambra-Moo et al. 2008; Sansom et al. 2013) suggest that factors affecting the rate of cadaver breakdown include temperature, moisture, $\mathrm{pH}$, oxygen, and the cause of death (Logan et al. 1991; Lyman 1994).

Fungi and insects are aerobic organisms that affect the surface of the cadaver (Logan et al. 1991; Lyman 1994; Downing and Park 1998; Carter et al. 2007). During decay, concentrations of carbon and nutrients increase in the soil surrounding a partially buried carcass and changes in $\mathrm{pH}$ occur as a result of decomposition. Corrosion of the upper surface of bones at the top of CRILAR-PV 601 is indirect evidence for the action of aerobic decay 

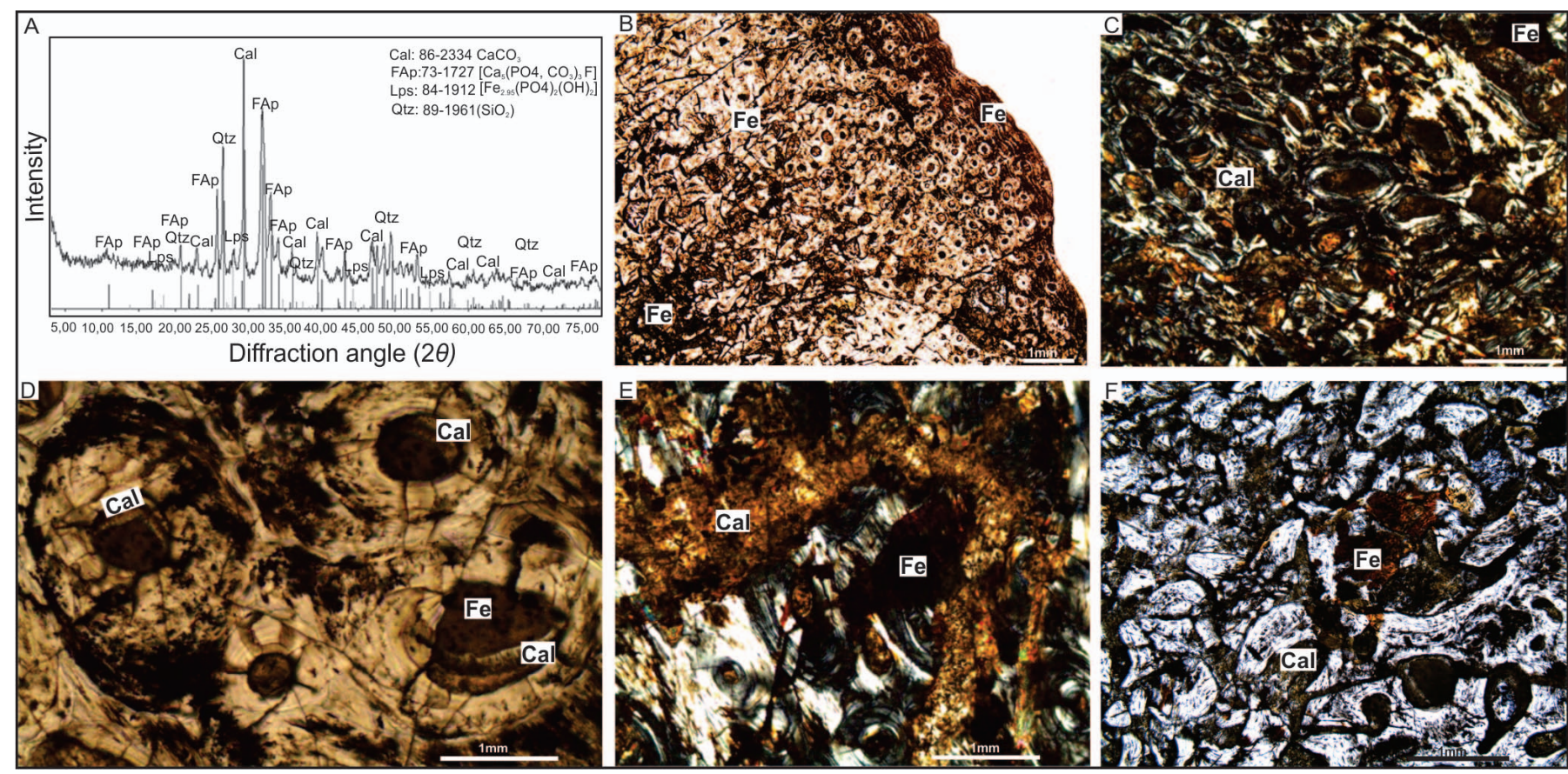

FIg. 11.-Bone diagenesis of the large non-mammalian therapsid rib in thin-sections. A) X-ray diffraction data of dicynodont rib. B) Parallel-fibered bone with simple canals and fractures filled by iron oxides. C) Secondary osteons filled by iron oxides and calcium carbonates. D) Detail of secondary osteons filled by fibrous calcite, and little black opaque minerals. E) Perimedullary region shows fractures cemented by microcrystalline calcite, and iron oxide patches. F) Medullary cavity with endosteal trabeculae and cancellous spaces cemented by calcite and iron oxides patches. Abbreviations: $\mathrm{Cal}=$ calcite; Fe $=$ iron. Photomicrographs in cross-polarized light. Scale bar $=1$ mm.

organisms such as fungi and insects (Lyman 1994; Downing and Park 1998; Carter et al. 2007). Clay mineralogy of the pedogenically altered fluvial deposits linked to the remains indicates that there was no strong seasonal climate effect locally in this area at the time of deposition.

Cadavers tend to be consumed (at least partly) in situ, which allows cadaveric material to enter the soil (Coe 1978). Thus, significant amounts of cadaveric material might only enter the soil when insects and microbes dominate cadaver decomposition prior to burial (Towne 2000). The burial of a cadaver in soil restricts the access of most insects and scavengers (Carter et al. 2007). The absence of these organisms results in significantly less cadaver decomposition than observed on the soil surface (Rodriguez and Bass 1985; Rodriguez 1997; VanLaerhoven and Anderson 1999; Fiedler and Graw 2003; Carter et al. 2007; Cambra-Moo et al. 2008). Bacteria are the main representatives of the anaerobic/aerobic decomposition that can act on the buried carcasses (Logan et al. 1991; Lyman 1994). Therefore, it is inferred that heterotrophic anaerobic/aerobic bacteria affected the chemical composition of the matrix immediately in contact with the CRILAR-PV 601 bone triggering the alkalinity engine that ultimately led to calcite precipitation (Dupraz et al. 2009) as evidenced by the clotted micrite.

\section{CONCRETIONS AS PRESERVATION ENHANCERS?}

Precipitation of carbonate cement decreases the sediment permeability around a decaying organism, inhibiting decay and enhancing preservation (McCoy et al. 2015). This process results in an increased preservation potential inside the concretion compared to the surrounding sediment (Downing and Park 1998; Rogers et al. 2001). However, McCoy et al. (2015) concluded that exceptional fossilization within concretions is not the result of a distinct concretion-forming process.

In soils, carbonate precipitation is critically dependent on atmospheric and soil partial pressures of $\mathrm{CO}_{2}$ (Retallack 2005). The carbonic acid, which originates from respired and atmospheric $\mathrm{CO}_{2}$ in the biological activity zone, hydrolyzes soil minerals, and is neutralized to precipitate carbonate below the acidic biological activity zone (Retallack 2005). Particularly in volcanic soils the availability of carbonates is related to different factors; in some cases the carbonatite ash promotes the carbonate concretions, but in other cases, the bone and/or soft tissue decomposition strongly induces their formation (e.g., Hay 1986; Downing and Park 1998; Rogers et al. 2001; McCoy et al. 2015). Downing and Park (1998) documented that when the hydroxyapatite is present in the host concretion, the bone material contributed to formation of diagenetic concretion. Thus, the sediments adjacent to the bone received and accumulated hydroxyapatite that was a product of bone dissolution. In contrast, when the bone material does not contribute to the formation of diagenetic concretions, carbonate supersaturation is required in the system, which can either occur throughout pore-waters, or be generated in situ by non-refractory organic matter decay, or created by inflowing external fluids (Raiswell and Fisher 2000). The EDX maps and XRD analysis in the CRILAR-PV 601 specimen display that P (fluorapatite) is present with a high concentration in the bones, but absent in the host rock. Similar results were documented by Rogers et al. (2001) in cases where the bone hydroxyapatite did not contribute to the concretion formation. Interestingly, the analysis performed on the CRILAR-PV 601 material shows that the tetrapod fossils recovered from the $\mathrm{CF}$, both from calcareous concretions or not, experienced similar diagenetic processes of permineralization, and revealed high concentration of $\mathrm{P}$ in the bones but not in the host rock. Moreover, the clotted micrite reported surrounding the study specimen, which is not included in a calcareous concretion, suggests that the soft-tissue decay promoted by bacteria is not linked with the carbonate concretion formation, but rather with the tetrapod permineralization. Consequently, this study reflects that quality of preservation is not linked to concretions formation in the CF.

Depositional environment and host-rock composition strongly influence preservation. Volcanism may enhance preservation in two principal ways: 

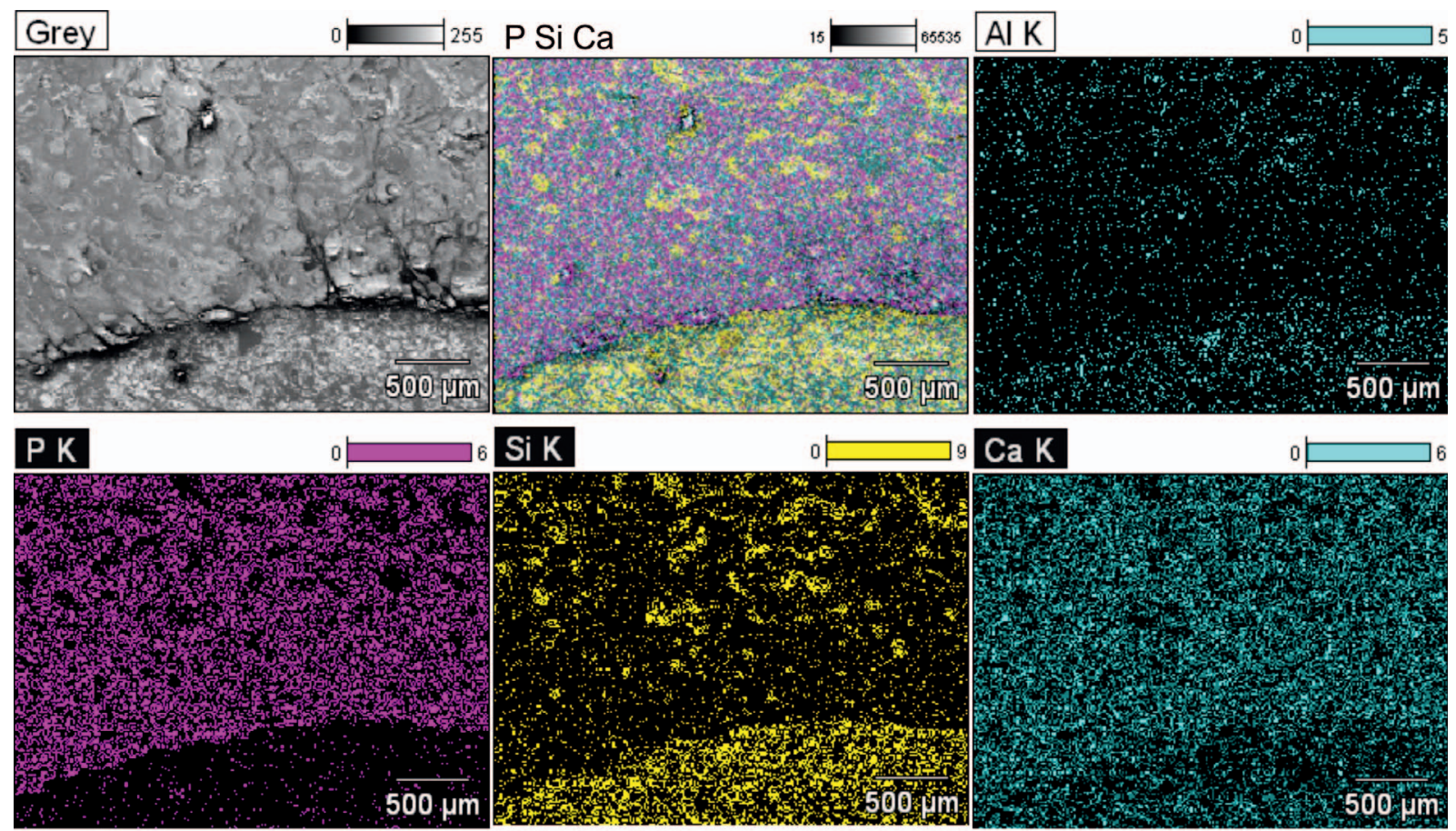

\section{Si K}

of

9 Ca K

$0{ }^{0}$

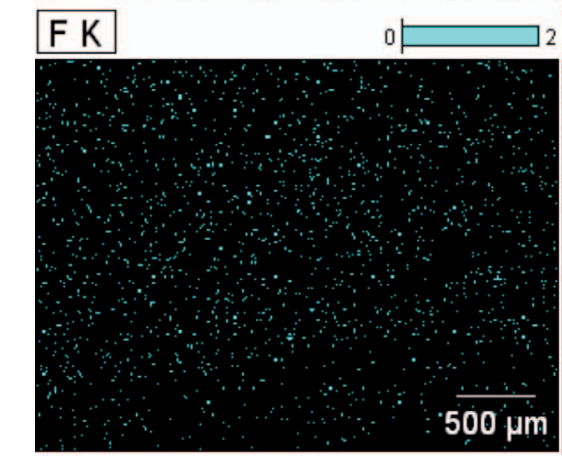

18
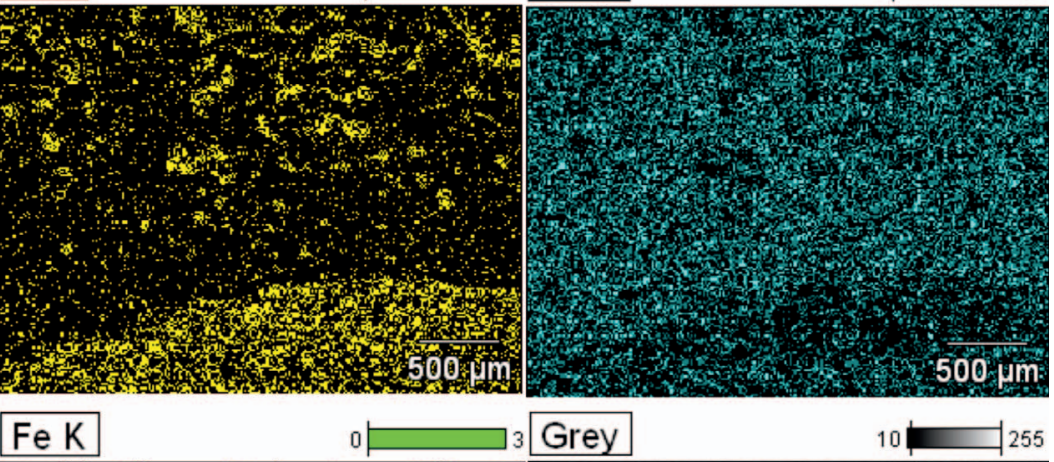

0

3 Grey

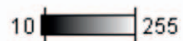

$\mathrm{PSi} \mathrm{Ca}$

${ }_{15}{ }_{60535}$ Grey

$500 \mu \mathrm{m}$

500 \%m


${ }_{6} \mathrm{P} \mathrm{K}$

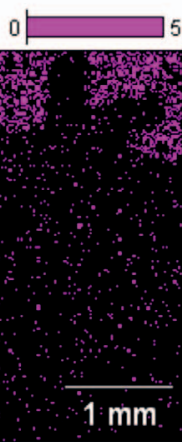

Si K

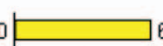

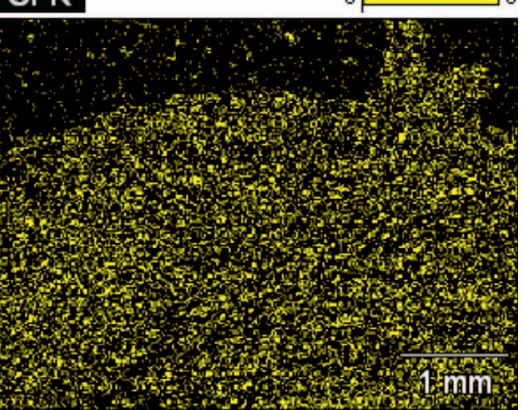



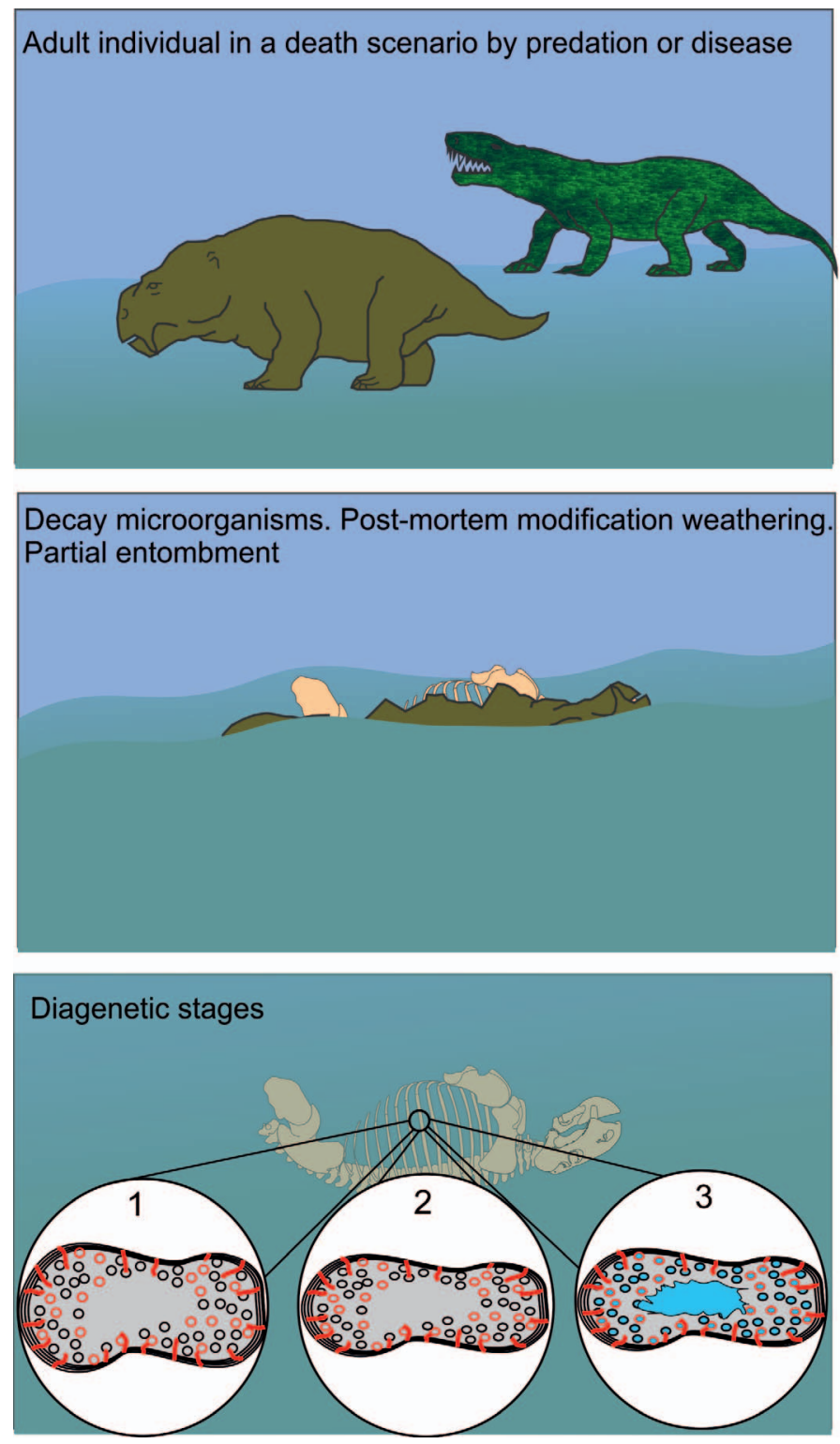
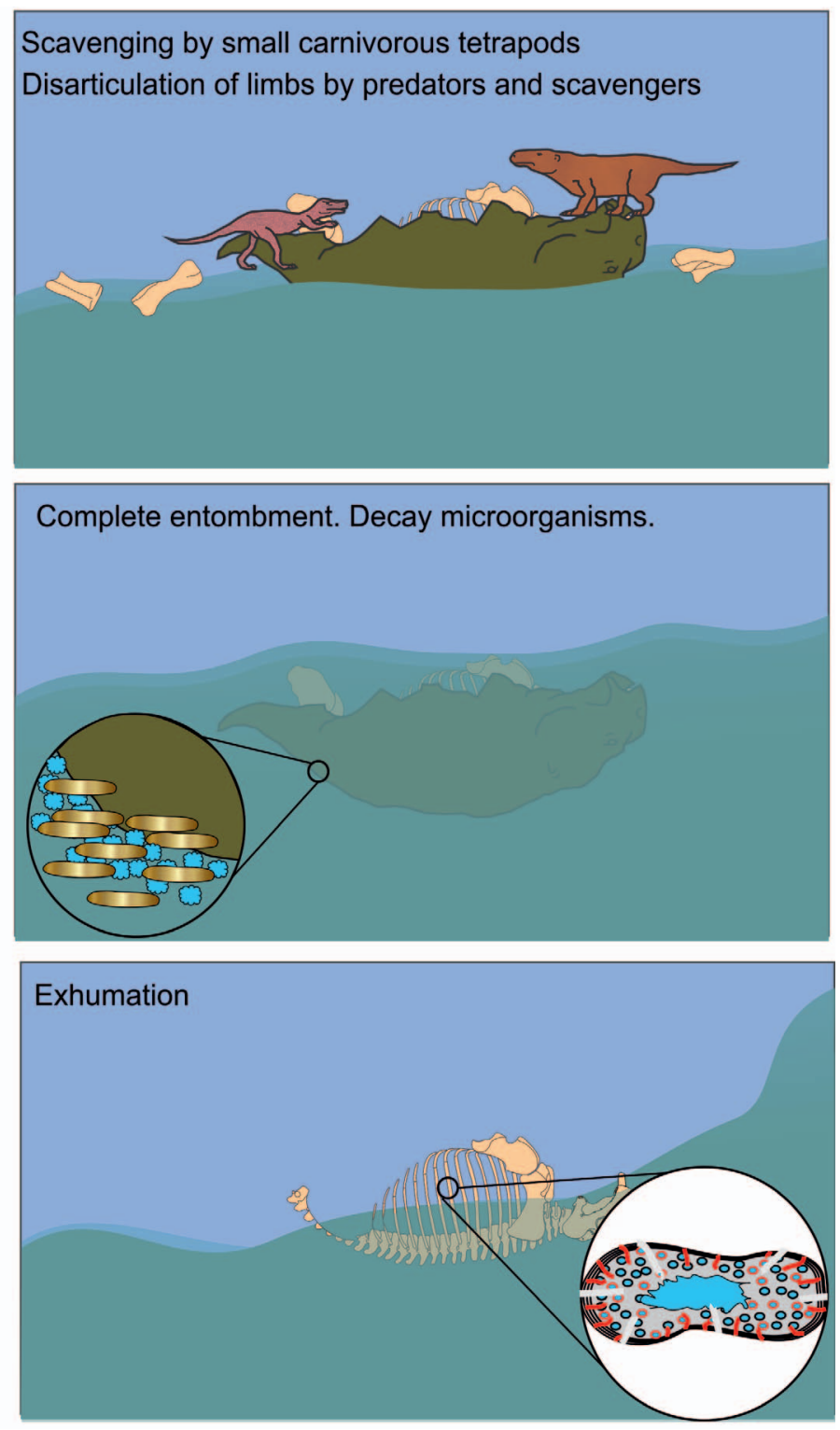

FIG. 13.- Summary of taphonomic history. Decay microorganisms promote the precipitation of biogenic micrite around the carcass. The irregular balloons represent the clotted texture and the fusiforms represent the microorganisms. Diagenesis stages: $1=$ iron oxides cementation in osteons, vascular canals, and fractures; $2=$ brittle deformation in vascular canals, trabeculae and pore spaces; 3 =calcite precipitation in vascular canals, cancellous spaces. Exhumation: the microstructure shows the transverse fractures without infill.

by rapid burial and by creating a favorable diagenetic environment that promotes preservation. The differences observed in the CF tetrapod fossils, such as weathering stage (0-1); articulation (from articulated skeleton to isolate and disperse elements); Voorhies group (I-III); orientation, among others (Mancuso et al. 2014), are strongly related to burial rate. The features observed on the bone surfaces are explained by the different exposure period on the soil surface. Therefore, the better preservation observed in the tetrapod fossils included in mass-mortality pathway is markedly linked with the rapid burial that these remains have experimented. Concerning the diagenetic environment, the CF includes several factors that promoted tetrapod preservation. The carbonatite ash chemically enhanced fossilization by providing an instant cement of sodium carbonate. Another factor is the abundant supply of calcium carbonate with an alkaline soil chemistry. Alkalinity is evidenced by the co-occurrence of calcite, phosphates, silica, and iron oxides, representing a mineral stability field of approximately $\mathrm{pH} 7$, in which bone apatite is relatively insoluble. A similar context was reported in East African paleosols (Hay 1986; Retallack 2007).

FIG. 12.-SEM image and EDX maps of the large non-mammalian therapsid rib in a thin-section. Gray is the SEM image in different points of the thin section. The multicolor is a superimposition of gray with $\mathrm{P}, \mathrm{Si}$, and Ca mapping. The color differences in the maps show the distribution of the different elements in the analyzed points. Abbreviations: $\mathrm{AlK}=$ Aluminum; $\mathrm{PK}=$ Phosphorus; $\mathrm{SiK}=$ Silica; $\mathrm{CaK}=$ Calcium; $\mathrm{FK}=$ Fluor; FeK $=\mathrm{Iron}$. 


\section{SUMMARY}

A large dicynodont skeleton was recently collected from an attritional mortality assemblage in the lower Chañares Formation. Detailed analysis of the specimen reveals that the individual was an adult. The most probable cause of death was predation or disease. During post-mortem exposure on the floodplain surface, the carcass was affected by vertebrate and invertebrate scavengers, subsequent subaerial decay, weathering, and incremental burial by subaqueous mud deposition in a floodplain. A portion of it disappeared, possibly due to scavenging, as transport seemed an unlikely cause. Post-burial, the skeleton suffered anaerobic decay and diagenetic modifications. The detailed study reveals evidence of two different stages of soft tissue decomposition, pre-burial by aerobic decay organisms (mainly insects and/or fungi) and post-burial by heterotrophic anaerobic/aerobic bacteria. Additionally, the detailed analysis has shown that early diagenesis in alluvial soils with high content of volcanic ash promoted excellent fossilization of the remains, whether or not they are included within calcareous concretions.

\section{ACKNOWLEDGMENTS}

We especially thank to reviewers, the Associate Editor, Simon Kay, Analia Forasiepi and R.M.H. Smith for improving the manuscript; and M. Bourguet (IANIGLA-CONICET), C. Marsicano (UBA-CONICET), C. Schultz (UFRGS), V. Krapovickas (UBA-CONICET), J.M. Leardi (UBA-CONICET), M. Becerra (CONICET), F. Garberoglio for their support during the fieldwork. The new specimen was prepared by M. Bourguet (IANIGLA-CONICET). For access permission, we thank Verónica Vargas and Laura Gachón (Dirección de Patrimonio Arqueológico y Paleontológico, Secretaría de Cultura de La Rioja) and Administración de Parques Nacionales. We are deeply indebted to the staff of Parque Nacional Talampaya for their constant assistance in the field and to Sergio Mosconi by the Tomographys made in the FUESMEN. The IANIGLACCT-Mendoza provided assistance during laboratory work (electron and petrographic microscopes). SEM and EDX analysis were provided by MEBYM (IANIGLA-CONICET) and XRD analysis was provided by INTEQUI (UNSLCONICET). Field and laboratory research was supported by the PIP CONICET 11420090100209/10 and PICT 2013-0805 (ACM). Additional financial support was provided by the Consejo Nacional de Investigaciones Científicas y Técnicas (CONICET).

\section{REFERENCES}

Allison, P.A. And Briggs, D.E.G., 1991, Taphonomy of nonmineralized tissues in P.A Allison and D.E.G. Briggs (eds.), Taphonomy: Releasing the Data Locked in the Fossil Record: Plenum Press, New York, p. 26-58.

Artabe, A.E., Morel, E.M., and Spalletti, L.A., 2003, Caracterización de las provincias fitogeográficas triásicas del Gondwana extratropical: Ameghiniana, v. 40, p. 387-405.

Ashley G.M. and Driese, S.G., 2000, Paleopedology and paleohydrology of a volcaniclastic paleosol interval: implications for early Pleistocene stratigraphy and paleoclimate record, Olduvai Gorge, Tanzania: Journal of Sedimentary Research, v. 70, p. $1065-1080$.

Bastin, G.F., Van Loo, F.J.J., and HeiJligers, H.J.M., 1986, Evaluation of the use of Gaussian $\varphi(\rho \mathrm{z})$ curves in quantitative electron probe microanalysis: a new optimization: X-Ray Spectrometry, v. 13, p. 91-97.

BehrenSMEYer, A.K., 1978, Taphonomic and ecologic information from bone weathering: Paleobiology, v. 4, p. 50-62.

BornemisszA, G.F., 1957, An analysis of arthropod succession in carrion and the effect of its decomposition on the soil fauna: Australian Journal of Zoology, v. 5, p. 1-12.

Cambra-Moo, O., Buscalioni, A.D., and Delgado-Buscalioni, R., 2008, An approach to the study of variations in early stages of Gallus gallus decomposition: Journal of Taphonomy, v. 6, p. 21-40.

Carter, D.O., Yellowlees, D., and Tibbett, M., 2007, Cadaver decomposition in terrestrial ecosystems: Naturwissenschaften, v. 94, p. 12-24.

CAselli, A.T., 1998, Estratigrafía y sedimentología de las formaciones Patquía (Pérmico) y Talampaya (Triásico inferior) en las Sierras Pampeanas Noroccidentales y Precordillera Central (provincias de La Rioja y San Juan): Universidad de Buenos Aires, Buenos Aires, Argentina, $437 \mathrm{p}$.

Caselli, A.T., Marsicano, C.A., And Arcucci, A.B., 2001, Sedimentología y paleontología de la Formación Los Colorados, Triásico superior (provincias de La Rioja y San Juan, Argentina): Revista de la Asociación Geológica Argentina, v. 56, p. 173-188.
Chinsamy, A. and Raath, M.A., 1992, Preparation of fossil bone for histological examination: Palaeontologia Africana, v. 29, p. 39-44.

CoE, M.J., 1978, The decomposition of elephant carcasses in the Tsavo (East) National Park, Kenya: Journal of Arid Environments, v. 1, p. 71-86.

Currie, B.S., Colombi, C.E., Tabor, N.J., Shipman, T.C., and Montañez, I.P., 2009, Stratigraphy and architecture of the Upper Triassic Ischigualasto Formation, Ischigualasto Provincial Park, San Juan, Argentina: Journal of South American Earth Sciences, v. 27, p. 74-87.

Davis, P.G. And Briggs, D.E.G., 1998, The impact of decay and disarticulation on the preservation of fossil birds: PALAIOS, v. 13, p. 3-13.

De Ricqlès, A., Meunier, F.J., Castanet, J., and Francilon-Vieillot, H., 1991, Comparative microstructure of bone, in B.K. Hall (ed.), Bone 3: Bone Matrix and Bone Specific Products: CRC Press Inc., Boca Raton, FL, p. 1-78.

Downing, K.F. AND PARK, L.E., 1998, Geochemistry and early diagenesis of mammalbearing concretions from the Sucker Creek Formation (Miocene) of southeastern Oregon: PALAIOS, v. 13, p. 14-27.

Dupraz, C., Reid, R.P., Braissant, O., Decho, A.W., Norman, R.S., and Visscher, P.T., 2009, Processes of carbonate precipitation in modern microbial mats: Earth-Science Reviews, v. 96, p. 141-162.

Eberth, D.A., Rogers R.R, AND Fiorillo A.R., 2007, A practical approach to the study of bonebeds, in R.R. Rogers, D.A. Eberth, and A.R. Fiorillo (eds.), Bonebeds: Genesis, Analysis, and Paleobiological Significance, The University of Chicago Press, Chicago, p. 265-332.

Fiedler, S. ANd Graw, M., 2003, Decomposition of buried corpses, with special reference to the formation of adipocere: Naturwissenschaften, v. 90, p. 291-300.

Fiorillo, A.R., 1988, Taphonomy of Hazard Homestead Quarry (Ogallala Group), Hitchcock County, Nebraska: Contributions to Geology, University of Wyoming, v. 26, p. $57-97$.

Francillon-Vieillot, H., De Buffrénil, V., Castanet, J., Géraudie, J., Meunier, F.J., Sire, J.Y., ZylberberG, L., AND DE Ricqlés, A., 1990, Microstructure and mineralization of vertebrate skeletal tissues, in J.G. Carter (ed.), Skeletal Biomineralization: Patterns, Processes and Evolutionary Trends, Volume 1: Van Nostrand Reinhold, New York, p. 471-530.

Gulbranson E.L., Montañez I.P. Tabor N.J., and Limarino C.O., 2015, Late Pennsylvanian aridification on the southwestern margin of Gondwana (Paganzo Basin, NW Argentina): a regional expression of a global climate perturbation: Palaeogeography, Palaeoclimatology, Palaeoecology, v. 417, p. 220-235.

HANSON, D.B. AND BuISKRA, J.E., 1987, Histomorphological alteration in buried human bone from the Lower Illinois Valley: implications for palaeodietary research: Journal of Archaeological Science, v. 14, p. 549-563.

HAY, R.L., 1986, Role of tephra in the preservation of fossils in Cenozoic deposits of East Africa, in L.E. Frostick, R.W. Renault, I. Reid, and J.-J. Tiercelin (eds.), Sedimentation in the African Rifts: Geological Society of America Special Publication 25, p. 339-344.

Kent, D.V., Santi Malnis, P., Colombi, C.E., Alcober O.A., and Martínez, R.N., 2014, Age constraints on the dispersal of dinosaurs in the Late Triassic from magnetochronology of the Los Colorados Formation (Argentina): Proceedings of the National Academy of Sciences, v. 111, p. 7958-7963.

KING, G., 1990, The Dicynodonts, A study in Palaeobiology: Chapman and Hall, London, 233 p.

KitchING, J.W., 1980, On some fossil Arthropoda from the Limeworks, Makapansgat, Potgietersrus: Palaeontologia Africana, v. 23, p. 63-68.

Krapovickas, V., Mancuso, A.C., Marsicano, C.A. Domnanovich, N, and Schultz, C, 2013, Large tetrapod burrows from the Middle Triassic of Argentina: a behavioural adaptation to seasonal semi-arid climates?: Lethaia, v. 46, p. 154-169.

Kutzbach J.E. And Gallimore R.G., 1989, Pangaean climates: megamonsoons of the Megacontinent: Journal of Geophysical Research, v. 94, p. 3341-3357.

Legarreta, L., Kokogian, D.A., And Dellapé D.A., 1992, Estructura terciaria de la Cuenca Cuyana: ¿Cuánto de inversión tectónica?: Revista de la Asociación Geológica Argentina, v. 47, p. $83-86$.

Logan, G.A., Collins, M.J., And Eglinton, G., 1991, Preservation of Organic Biomolecules, in P.A. Allison and D.E.G. Briggs (eds.), Taphonomy: Releasing the Data Locked in the Fossil Record: Plenum Press, New York, p. 1-18.

Lucas, J. And PrÉvôt, L.E., 1991, Phosphates and fossil preservation, in P.A. Allison and D.E.G. Briggs (eds.), Taphonomy: Releasing the Data Locked in the Fossil Record: Plenum Press, New York, p. 389-409.

Lyman, R.L., 1994, Vertebrate Taphonomy: Cambridge University Press, Cambridge, $524 \mathrm{p}$.

MackenZie, W.S. And Guilford, C., 1980, Atlas of Rock-Forming Minerals in Thin Section: John Wiley and Sons, New York, 103 p., ISBN 13: 9780470269213.

Mancuso, A.C., 2005, Revisión y aportes a la estratigrafía de la sección inferior del Grupo Agua de la Peña (Triásico Medio, Argentina): XVI Congreso Geológico Argentino, La Plata, Argentina, Actas 3, p. 415-422.

Mancuso, A.C. and Caselli, A.T., 2012, Paleolimnology evolution in rift basins: the Ischigualasto-Villa Unión Basin (Central-Western Argentina) during the Triassic: Sedimentary Geology, v. 275-276, p. 38-54.

Mancuso, A.C., Gaetano, L.C., Leardi, J.M., Abdala, F., and Arcucci, A.B., 2014, The Chañares Formation: a window to the palaeobiology of a Middle Triassic vertebrate fauna: Lethaia, v. 47, p. 244-265. 
Marsicano, C., Irmis, R., Mancuso, A.C., Mundil, R., and Chemale, F., 2015, The precise temporal calibration of dinosaur origins: Proceedings of the National Academy of Sciences of the United States of America, v. 113, p. 509-513.

Marsicano, C., Mancuso, A., Palma, R., and Krapovickas, V., 2010, Tetrapod tracks in a marginal lacustrine setting (Middle Triassic, Argentina): taphonomy and significance: Palaeoecology, Palaeogeography, Palaeoclimatology, v. 291, p. 388-399.

Martinez, R.N., Sereno, P.C., Alcober, O.A., Colombi, C.E., Renne, P.R., Montañez, I.P., AND Currie, B.S., 2011, A basal dinosaur from the dawn of the Dinosaur Era in Southwestern Pangaea: Science, v. 331, p. 206-210.

McCoy, V.E., Young, R.T., AND BRIGGs, D.E.G., 2015, Factors controlling exceptional preservation in concretions: PALAIOS, v. 30, p. 272-280.

Oliveira Bueno, De, A., 2012, Evidências de gregarismo e construção de toca em Dinodontosaurus turpior (Therapsida, Anomodontia) do Triássico Médio do Rio Grande do Sul, Brasil: Universidade Federal do Rio Grande do Sul, 51 p.

Oliveira Bueno, De, A., Cisneros, J.C., And Schultz, C.L., 2011, Evidence of gregarious and burrowing habits in Dinodontosaurus turpior (Therapsida, Dicynodontia) from the Triassic Santa Maria Formation of Rio Grande do Sul, Brazil: Ameghiniana, v. 48, p. 39.

Parrish, J., 1993, Climate of the Supercontinent Pangea: The Journal of Geology, v. 101, p. 215-233.

PAYNE J.A., 1965, A summer carrion study of the baby pig Sus scrofa Linnaeus: Ecology, v. 46 , p. $592-602$

Petrisor, A.I. And Decho, A.W., 2004, Using geographical information techniques to quantify the spatial structure of endolithic boring processes within sediment grains of marine stromatolites: Journal of Microbiological Methods, v. 56, p. 173-180.

Piepenbrink, H., 1986, Two examples of biogenous dead bone decomposition and their consequences for taphonomic interpretation: Journal of Archaeological Science, v. 13, p. 417-430.

Pirrone, C.A., Buatois, L.A., And Bromley, R.G., 2014, Ichnotaxobases for bioerosion trace fossils in bones: Journal of Paleontology, v. 88, p. 195-203.

Previtera E., D'Angelo, J.A., and Mancuso, A.C., 2013, Bone diagenesis of Early Triassic cynodonts (Mendoza, Argentina): a chemometric approach: Ameghiniana, v. 50 p. $460-468$.

Previtera E., Mancuso, A.C., De La Fuente, M.S., and Sánchez, E.S., 2016, Diagenetic analysis of tetrapod from the Upper Triassic, Puesto Viejo Group, Argentina: Andean Geology, v. 43, p. 197-214.

RAISWELl, R. AND FisheR, Q.J., 2000, Mudrock-hosted carbonate concretions: a review of growth mechanisms and their influence on chemical and isotopic composition: Journal of the Geological Society, v. 157 , p. 239-251.

Ray, S., Bandyopadhyay, S., and Appana, R., 2010, Bone histology of a Kannemeyeriid Dicynodont Wadiasaurus: palaeobiological implications, in S. Bandyopadhyay (ed.), New Aspects of Mesozoic Biodiversity: Lecture Notes in Earth Sciences 132, SpringerVerlag Berlin Heidelberg, p. 73-89, doi: 10.1007/978-3-642-10311-7-5.

Ray, S. and Chinsamy, A., 2004, Diictodon feliceps (Therapsida, Dicynodontia): bone histology, growth and biomechanics: Journal of Vertebrate Palaeontology, v. 24, p. 180 194

REID, R.E.H., 1996, Bone histology of the Cleveland-Lloyd dinosaurs and of the dinosaurs in general, Part I, Introduction to Bone Tissues: Geology Studies v. 41, p. 25-71.
Retallack, G.J., 2005, Pedogenic carbonate proxies for amount and seasonality of precipitation in paleosols: Geology, v. 33, p. 333-336.

Retallack, G.J., 2007, Paleosols, in W. Henke and I. Tattersall (eds.), Handbook of Paleoanthropology, Volume 1, Principles, Methods and Approaches: Springer, Berlin, p. $383-408$.

RoDRIGUEZ, W.C., 1997, Decomposition of buried and submerged bodies, in W.D. Haglund and M.H. Sorg (eds.), Forensic Taphonomy: The Postmortem Fate of Human Remains: CRC Press, Boca Raton, p. 459-468.

RodrigueZ, W.C. AND BASS, W.M., 1985, Decomposition of buried bodies and methods that may aid in their location: Journal Forensic Science, v. 30, p. 836-852.

Rogers, R.R., 1992, Non-marine borings in dinosaur bones from the Upper Cretaceous Two Medicine Formation, northwestern Montana: Journal of Vertebrate Paleontology, v. 12 , p. $528-531$.

Rogers, R.R., Arcucci, A.B., Abdala, F., Sereno, P.C., Forster, C.A. and May, C.L., 2001, Paleoenvironment and taphonomy of the Chañares Formation tetrapod assemblage (Middle Triassic), northwestern Argentina: spectacular preservation in volcanogenic concretions: PALAIOS, v. 16, p. 461-481.

Romer, A. And Jensen, J., 1966, The Chañares (Argentina) Triassic reptile fauna, II, sketch of the geology of the Rio Chañares, Rio Gualo region: Breviora, v. 252, p. 1-20.

Sansom, R.S., GabBott, S.E., And Purnell, M.A., 2013, Atlas of vertebrate decay: a visual and taphonomic guide to fossil interpretation: Palaeontology, v. 56, p. 457-474.

StiPanicic, P.N., 2002, Introducción, in P.N. Stipanicic and C. Marsicano (eds.), Léxico Estratigráfico de la Argentina: Triásico: Asociación Geológica Argentina, Serie B (Didáctica y Complementaria), v. 26, p. 1-24.

Tabor, N.J., Montañez, I.P., Kelso, K. A. Currie, B., Shipman, T. and Colombi, C., 2006, A Late Triassic soil catena: landscape and climate controls on paleosol morphology and chemistry across the Carnian-age Ischigualasto-Villa Union basin, northwestern Argentina: The Geological Society of America Special Paper, v. 416, p. 17-41.

Terry, D.O., Lagarry, H.E., and Hunt JR., R.M., 1998, Depositional environments, lithostratigraphy, and biostratigraphy of the White River and Arikaree Groups: (late Eocene to early Miocene, North America): The Geological Society of America Special Paper, v. 325, $211 \mathrm{p}$

Towne, E.G., 2000, Prairie vegetation and soil nutrient responses to ungulate carcasses: Oecologia, v. 122 , p. $232-239$

Trueman, C.N.G., Behrensmeyer, A.K., Tuross, N., And Weiner, S., 2004, Mineralogica and compositional changes in bones exposed on soil surfaces in Ambosely Nationa Park, Kenya: diagenetic mechanism and the role of sediment pore fluids: Journal of Archaeological Science, v. 31, p. 721-739

Uliana, M.A. And Biddle, K., 1988, Mesozoic-Cenozoic paleogeographic and geodynamic evolution of southern South America: Revista Brasileira de Geociências, v. 18 , $172-190$.

Vanlaerhoven, S.L. and Anderson, G.S., 1999, Insect succession on buried carrion in two biogeoclimatic zones of British Columbia: Journal Forensic Science, v. 44, p. 32-43.

WiLson, J.W., 1994, Histological techniques, in P. Leiggi and P. May (eds.), Vertebrate Paleontological Techniques: Cambridge University Press, New York, v. 1, p. 205-234.

Received 29 July 2016; accepted 26 January 2017 